\title{
ALIMENTACIÓN Y ASISTENCIA EN LA PALENCIA FESTIVA A FINALES DEL ANTIGUO RÉGIMEN (1700-1833)*
}

\author{
Food and Assistance in the Festive Palencia at the End \\ of the Old Regime (1700-1833)
}

\author{
Diego QUIJADA ÁLAMO \\ Instituto Universitario de Historia Simancas \\ diegoquijada@hotmail.com
}

Fecha de recepción: 14/06/2020

Fecha de aceptación definitiva: 18/03/2021

RESUMEN: El presente trabajo se centra en dos cuestiones poco estudiadas que giran alrededor de las ceremonias públicas de Palencia en la Edad Moderna (17001833). Por un lado, abordamos un elemento interno que afecta a los promotores o a una élite, como es la alimentación, es decir, la comida y la bebida propias de los banquetes y colaciones organizados por las autoridades municipales con motivo de una celebración extraordinaria. Por otro lado, un elemento externo, ajeno a los hacedores, en el que analizamos la caridad ejercida por los poderes públicos en las jornadas festivas desde una óptica benéfico-asistencial (doncellas huérfanas, mendigos, enfermos, labradores empobrecidos, presos) y cultural, centrada en los

* Este trabajo se ha realizado en el marco del Proyecto «Mujeres, familia y sociedad. La construcción de la historia social desde la cultura jurídica (siglos XVI-XX)» (PID2020-117235GB-I00), financiado por el Ministerio de Ciencia e Innovación.

Para la realización de esta investigación han sido consultados diversos fondos procedentes del Archivo Municipal de Palencia (AMP), Archivo Histórico Provincial de Palencia (AHPP), Archivo de la Catedral de Palencia (ACP), Archivo General de Palacio (AGP), Archivo Histórico Nacional (AHN), Real Biblioteca del Monasterio de El Escorial (RBME).

Equivalencia de pesos y medidas que aparecen en este trabajo: fanega ( 55 litros y medio); cántara (16 litros); azumbre (2 litros); celemín ( 4 cuartillos); cuartillo ( $1 \frac{2}{2}$ litro); quintal (100 libras, unos 46 kilogramos); arroba (25 libras); libra (16 onzas, unos 460 gramos). 
concursos de exámenes de niños de escuela con ocasión de la celebración de la onomástica del rey.

Palabras clave: fiesta pública; sociabilidad festiva; alimentación; caridad; Palencia; Antiguo Régimen.

ABSTRACT: This paper focuses on two little-studied issues concerning Palenciás public ceremonies in the Modern Age (1700-1833). On the one hand, we deal with an internal element that affects the promoters or an elite, such as food, that is to say, the typical food and drinks of the banquets and snacks organized by the municipal authorities on the occasion of an extraordinary celebration. On the other hand, an external element, unconnected to the makers, in which we analyze the charity exercised by the public authorities during festive days from a philanthropic assistance (orphaned maidens, beggars, sick people, impoverished farmers, prisoners) and cultural point of view, centered on the competitions of school children's exams on the occasion of the celebration of the king's onomastics.

Key words: public celebration; festive sociability; food; charity; Palencia; Ancien Regime.

\section{INTRODUCCIÓN}

Durante mucho tiempo la historia de los grandes acontecimientos protagonizados por hombres extraordinarios se ha identificado esencialmente con la historia política. Pero desde hace algunas décadas la perspectiva se ha visto ampliada y la «nueva historia» ha multiplicado los sujetos y los temas de estudio, centrándose en la gente común y corriente y en los comportamientos colectivos de todos los estamentos de la sociedad.

Dentro de esta corriente conviene destacar la importancia de la fiesta como elemento imprescindible de las sociedades humanas. Innumerables fueron en el Antiguo Régimen las ceremonias públicas ${ }^{1}$, «aquellas que son promovidas por las

1. Cuantiosos son los estudios dedicados a la fiesta, por lo que señalamos algunas de las obras más destacadas: BONET CORREA, Antonio. Fiesta, podery arquitectura. Aproximaciones al Barroco español. Madrid: Akal, 1990; NúÑEz Rodríguez, Manuel (coord.). El rostro y el discurso de la fiesta. Santiago de Compostela: Universidad de Santiago, 1994; López LóPEz, Roberto Javier. "Celebraciones públicas en Galicia durante el siglo XVIII". Obradoiro de Historia Moderna, 1992, 1, pp. 185-204; del mismo autor: Ceremonia y poder en Galicia a finales del Antiguo Régimen. Santiago de Compostela: Universidad de Santiago, 1995; GonzÁlez Enciso, Agustín y Usunáriz GarayoA, Jesús María (dirs.). Imagen del rey, imagen de los reinos. Las ceremonias públicas en la España Moderna (1500-1814). Pamplona: Eunsa, 1999; Bravo Lara, María Dolores. "La fiesta pública: su tiempo y su espacio». En RuBial GaRCía, Antonio (coord.). La ciudad barroca. México: Fondo de Cultura Económica, 2005, pp. 435-460; DíAZ JimÉNEZ, Isidro. "Aproximación al estudio de las celebraciones públicas en Sevilla durante el siglo XVIII». En NÚÑEZ ROLDÁN, Francisco (coord.). Ocio y vida cotidiana en el mundo hispánico en la Edad Moderna. Sevilla: Universidad de Sevilla, 2007, pp. 331-351; SERrano MarTín, Eliseo. "Imágenes del rey 
autoridades para celebrar o conmemorar de manera extraordinaria un acontecimiento y que por lo tanto no están previstas en el calendario ${ }^{2}$. El advenimiento al trono de un nuevo rey, el nacimiento de un príncipe o infante, la celebración de un tratado de paz, el recibimiento de un obispo o la canonización de un santo forman parte del elenco de ceremonias públicas, pues la proyección de la imagen del poder -concebida al mismo tiempo como mecanismo de legitimación- a través del aparato festivo buscaba enaltecer a la Monarquía -el rey en primer lugar-, a las autoridades eclesiásticas y a los poderes civiles.

Uno de los logros más interesantes relacionado con las ceremonias públicas ha sido el acercamiento a la vida cotidiana como objeto de investigación histórica ${ }^{3}$, dado que su ámbito abarca el ocio y la diversión, así como los diversos aspectos relacionados con la cultura popular ${ }^{4}$, pero también con la necesidad vital del ser humano, como la alimentación en los momentos de regocijo o la caridad destinada a ayudar a los más desfavorecidos de la sociedad durante las jornadas festivas.

En este trabajo analizaremos los alimentos consumidos por las autoridades urbanas e invitados distinguidos en los banquetes, "refrescos» y ambigús organizados al hilo de las celebraciones públicas en Palencia al final de la Edad Moderna, pero también dedicaremos especial atención a la vertiente benéfico-asistencial de la fiesta a través de las limosnas, dotes y alimentos entregados por el municipio a los más desfavorecidos (doncellas y niños huérfanos, pobres, enfermos, labradores y artesanos empobrecidos), incluidos los indultos para presos concedidos por los monarcas en celebraciones señaladas. Por otro lado, abordaremos la faceta cultural de las festividades mediante la organización de exámenes de niños en edad de escolarización con motivo de la onomástica del rey.

e identidad del reino en los rituales y celebraciones públicas en Aragón en el siglo XVI». Obradoiro de Historia Moderna, 2011, 20, pp. 43-71; BAEna Gallé, José Manuel. La ciudad en fiestas. Celebraciones públicas en Sevilla durante la Guerra de la Independencia. Sevilla: Diputación Provincial, 2019.

2. LóPEz LóPEz, Roberto Javier. Ceremonia y poder..., op. cit., pp. 12-13.

3. Sobre cultura material y vida cotidiana señalamos algunas obras: NúÑ̃z RoLDÁn, Francisco. La vida cotidiana en la Sevilla del Siglo de Oro. Madrid: Sílex, 2004; García Fernández, Máximo (coord.). Cultura material y vida cotidiana moderna: escenarios. Madrid: Sílex, 2013; GARCía HuRTADO, Manuel-Reyes (ed.). La vida cotidiana en la España del siglo XVIII. Madrid: Ś́lex, 2009.

4. BURKE, Peter. La cultura popular en la Europa moderna. Madrid: Alianza, 1996; SchulTz, Uwe (coord.). La fiesta: una historia cultural desde la antigüedad hasta nuestros días. Madrid: Alianza, 1993. 


\section{De la ALIMENTACiÓN COTIDIANA A LA ALIMENTACIÓN FESTIVA}

2.1. La alimentación posible de los palentinos: algo más que el pan nuestro de cada día

Entre las múltiples ocupaciones cotidianas de los hombres y mujeres en la Edad Moderna, una de las más destacadas era la alimentación 5 . Sin embargo, esta necesidad vital del ser humano ha pasado a convertirse en un fenómeno cultural con un claro significado de distinción social ${ }^{6}$.

La alimentación moderna se basaba principalmente en un triángulo: pan, vino y carne. Pero existía gran desigualdad en función del estamento social, pues mientras los dos primeros eran los alimentos generales, la carne, sobre todo la de mayor calidad, no estaba al alcance de todos, pues su consumo solía darse en personas con mayor poder adquisitivo. De esta forma, los guisos y asados de cerdo, vaca y ternera, carnero, lechazo y conejo constituían una parte esencial de su dieta diaria, incluyendo también la volatería, de corral o caza, como pollos, gallinas, capones, pavos, gansos, pichones, palominos ${ }^{7}$, perdices y faisanes. En cambio, la gente pobre tenía que conformarse con la casquería y las vísceras que comercializaban a bajo coste las "triperas y mondongueras", aquellas mujeres que "disponían, guisaban y vendían los mondongos", es decir, las asaduras del carnero y ganado vacuno principalmente 9 . Por otro lado, el tocino era la grasa más frecuente en todas las cocinas.

No son muchos los datos que se pueden ofrecer acerca del pescado, necesario durante la cuaresma, pues este escaseaba en las ciudades del interior

5. De la obra clásica de MONTANARI, Massimo. El hambre y la abundancia: historia y cultura de la alimentación en Europa. Barcelona: Crítica, 1993, a obras más recientes: FLANDRIN, Jean-Louis y Montanari, Massimo (dirs.). Historia de la alimentación. Gijón: Trea, 2011; PÉrez SAmper, María Ángeles. Mesas y cocinas en la España del siglo XVIII. Gijón: Trea, 2011; de esta misma autora, Comery beber: una historia de la alimentación en España. Madrid: Cátedra, 2019; CAMPILlo ÁlvarEz, José Enrique; RuCQuOI, Adeline; PÉrez SAMPER, María Ángeles y LóPEz TERRADA, María Luz. Comer a lo largo de la historia. Valladolid: Universidad de Valladolid, 2015; CHAín, Andrés. La alimentación en la historia. Salamanca: Universidad de Salamanca, 2018; BAGES-QuEROL BLANCO, Jordi. La alimentación en la Edad Moderna: la cocina en la Cataluña del siglo XVIII. Barcelona: OUC, 2019.

6. En esta línea resultan interesantes tres trabajos: MONTANARI, Massimo. La comida como cultura. Gijón: Trea, 2006; FlANDRIN, Jean-Louis. «Historia de la alimentación: por una ampliación de las perspectivas». Manuscrits, 1987, 6, pp. 7-30; PÉREZ SAMPER, María Ángeles. "La historia de la historia de la alimentación». Chronica Nova, 2009, 35, pp. 105-162.

7. La diferencia entre el pichón y el palomino reside en que el primero es la cría de la paloma doméstica y el segundo es la cría de la paloma silvestre.

8. RAE, Diccionario de Autoridades, tomo IV, 1734, vOZ «mondonguera».

9. Sirva de ejemplo el precio que tenían los despojos de las reses vacunas en Palencia a la altura de 1797. Así, la libra de callos limpios costaba 22 maravedís, la libra de lengua con papada y esófago (40 maravedís), la sesada (34 maravedís), la libra de cabeza (22 maravedís), cada oreja pelada y limpia (20 maravedís), la libra de asadura (22 maravedís), la libra de hocico (22 maravedís), manos y pies (40 maravedís), la vara de tripas (8 maravedís) y la libra de sangre (12 maravedís). 
peninsular y su precio solía ser elevado, sobre todo si se trataba de producto fresco, pues el pescado salado o curado tenía connotaciones de pobreza e inferioridad social. El principal río de la ciudad -el Carrión- contaba con algo de pesca relativa a "barbos, algunas anguilas y truchas»" ${ }^{10}$, mientras que la documentación municipal menciona cierto consumo de abadejo, congrio fresco y seco y besugo ${ }^{11}$.

Las verduras y legumbres eran el complemento obligado de la dieta diaria, ingrediente básico de los tradicionales cocidos y sopas, plato principal de las comidas de este periodo. La fruta fresca, en cambio, era poco valorada dietéticamente, y se consumía por gusto. En Palencia a mediados del siglo XVIII se cultivaba «todo género de hortaliza, frutas de fin de estío y algunas semillas potageras, todo de la mejor calidad ${ }^{12}$. El libro inventario de 1751 nos da una idea de la variedad: cereales (trigo, cebada, centeno y avena), verduras y hortalizas de regadío (cebollas, escarolas, pepinos, calabazas, zanahorias, nabos y cardos) y algunas frutas, como peras, manzanas, ciruelas, membrillos, moras y melocotones ${ }^{13}$.

Pero los palentinos en la centuria ilustrada también consumían otros alimentos. Un asiento municipal de 1741 -el pleno del Ayuntamiento decidió gravar el $10 \%$ en el precio de determinados alimentos exóticos, así como en ciertas frutas verdes y secas- permite conocer con detalle algunos de los comestibles: uvas, guindas, cerezas, manzanas camuesas y esperiegas, naranjas, limones, limas, sandías, melones, albaricoques, higos de Córdoba y Alicante, aceitunas sevillanas, uvas pasas de Ceclavín (provincia de Cáceres), orejones, higos secos, avellanas en casco y tostadas, almendras del baile ${ }^{14}$, piñones en casco y mondados, nueces, castañas en casco y castañas pilongas. Por último, destacan los géneros ultramarinos, importados de América o Asia, auténticos bienes de lujo reservados a una

10. AMP, Administración, Patrimonio, Libro inventario de propiedades de la ciudad de Palencia, 1751, caja 132, f. 40v.

11. En contraposición destaca el escaso rendimiento económico de esta actividad tras comprobar cómo el Concejo llegó a encomendar a Manuel Maestro a partir de 1802 la venta y expedición al por menor de escabeches y pescados frescos, pues el miserable sueldo de pregonero no le permitía vivir únicamente de su oficio. AMP, Actas Municipales, 29/11/1802, ff. 367v.-368v.

12. Argüello CaSTRIllo, Agustín. Dictamen físico-médico-político sovre la epidemia de tercianas que por cerca de tres años reyna en el Pays de Campos, y particularmente en su capital, la ciudad de Palencia. Palencia: Imprenta de Álvarez, 1802, p. 5.

13. AMP, Administración, Patrimonio, Libro inventario de propiedades de la ciudad de Palencia, 1751, caja 132, f. 4r.

14. Se trata de una variedad de "almendras gruesas", en Terreros PANDo, Esteban de. Diccionario castellano con las voces de ciencias y artes y sus correspondientes en las tres lenguas francesa, latina e italiana, tomo I. Madrid: En la imprenta de la viuda de Ibarra, hijos y compañía, 1786, p. 205, VOZ «almendras del baile». Esta variedad de fruto seco aparece ya citada en La bumildad coronada de las plantas (1644), auto sacramental alegórico de Pedro Calderón de la Barca: «Y si vamos a los frutos, / ¿en qué banquete opulento / no soy principio? Y en fin, / pues de mí para este efecto / se hacen también los turrones, / almendradas para el sueño, / aceites de almendras dulces, / almendrones, caramelos, / y peladillas tostadas. / [...] Cuerpo de Dios, que das vino, / que es el mejor compañero / de mis almendras del baile». 
minoría de la población, como las especias (pimienta, clavo, azafrán y canela), el azúcar, el cacao y el chocolate labrado.

Las bebidas habituales eran el agua y el vino, este mucho más apreciado por sus cualidades energéticas y euforizantes. En el Antiguo Régimen todos bebían vino, hombres y mujeres, niños y adultos, pobres y ricos. A partir del siglo XVIII se extendió la moda de consumir bebidas frías, como la horchata, el sorbete, la leche de almendras, las aguas de cebada y avena y otras bebidas refrescantes ${ }^{15}$. A partir de 1784 su precio fue regulado por una normativa municipal para no perjudicar a los palentinos, permitiendo, al mismo tiempo, obtener una moderada ganancia a los botilleres. Así, la lista de refrescos quedó fijada con los siguientes precios $^{16}$ : el cuartillo de agua de nieve (dos maravedís), el de aloja -bebida hecha con agua, miel y especias- (dos cuartos), agua de cebada (cuatro cuartos), agua de limón, agua de China y agua de agraz ${ }^{17}$ (nueve cuartos, es decir, 34 maravedís), el cuartillo de agua de canela $^{18}$, el de aurora -elaborada con leche de almendras y agua de canela- y agua de melocotón, albaricoque, guinda y sandía (diez cuartos), horchata (once cuartos), leche (doce cuartos) y el de sorbete de limón, agua de China, agraz imperial ${ }^{19}$, melocotón, guinda, sandía, canela y mantecada (diez y ocho cuartos).

Por otra parte, existía gran variedad de licores y aguardientes, que se despachaban en tabernas y figones, pero también en los estancos de licores, arrendados en su mayoría por el Ayuntamiento. El libro de cuentas de propios y arbitrios de 1758, que está dedicado íntegramente a los gastos de la administración de esta renta, da cuenta del amplio surtido ${ }^{20}$. El aguardiente era la bebida alcohólica más apreciada después del vino, pues experimentó un auge de su consumo a partir del siglo XVIII ${ }^{21}$. La mistela se elaboraba con aguardiente, agua, azúcar y canela, aunque podía ser además una especie de vino preparado con mosto de uva al que se le añadía alcohol. El resolí (o rosolî) era un licor que también se hacía con aguardiente y azúcar y algunos ingredientes olorosos, como el anís, la canela, el

15. Sobre refrescos puede verse el trabajo de PÉREZ SAMPER, María Ángeles. "Luces, tertulias, cortejos y refrescos". Cuadernos de Estudios del Siglo XVIII, 2000-2001, 10-11, pp. 107-153.

16. AMP, Actas Municipales, 28/05/1784, f. 213r. El real de vellón equivale a 34 maravedís (9 cuartos).

17. El agraz es una fruta parecida a la uva que no ha madurado, que se emplea como bebida, ingrediente de salsas o condimento. A partir del siglo XVIII fue desplazado por el limón.

18. «Bebida que se hace cociendo la canela, y después el agua se incorpora con almíbar de azúcar». RAE, Diccionario de Autoridades, tomo II, 1729, voz "canela».

19. Se trata de una especie de granizado a base de zumo ácido de uva verde, almendras y azúcar, de sabor acidulado, que se sirve en grandes copas de sorbete.

20. AMP, Hacienda, Bienes y cuentas de Propios y Arbitrios, caja 571, libro de cuentas de 1758 relativo a licores y aguardientes.

21. Prado AnTúneZ, Ana Isabel. «Fiestas, romerías y bailes en el Bilbao del Antiguo Régimen: mecanismos de control y evolución de la fiesta y la comensalidad». Bidebarrieta, 2014, 25, p. 63. 
limón, las guindas o el ajenjo ${ }^{22}$. La leche virginal era un licor compuesto por aguardiente refinado, benjuí (resina olorosa de un árbol utilizada desde la antigüedad), estoraque (licor procedente de la corteza del árbol del mismo nombre), espliego, flor de romero, almizcle y ámbar gris (secreción producida por el cachalote) que, mezclado en un alambique y destilado, ofrecía un color similar al de la leche. Por último, existían dos líquidos que con el tiempo se convirtieron en remedios medicinales, como el agua del Carmen, un licor elaborado por primera vez por los carmelitas descalzos cuyo origen se documenta en Francia a inicios del siglo XVII, o productos de cosmética, como el agua de la reina de Hungría, que se obtenía destilando la flor de romero con aguardiente.

Muchos de los "propios» relativos al ramo de la alimentación que existían en la ciudad estaban arrendados por el Ayuntamiento: mesón de la fruta y tabernilla del vino, peso de la harina, pan, legumbres, pescados frescos, pollo, aguardiente y licores, matadero y cebadero, carnes, abasto del tocino y pozos de la nieve. Por otro lado, el Cabildo -la otra institución fuerte, además del Concejo- ejercía un estricto control sobre los arrendamientos de sus ingresos ${ }^{23}$, incluidos los diezmos de la cuenta de granos, las rentas mayores de los préstamos pertenecientes a la Mesa capitular (pollos, corderos, conejos, leche, queso, cera y miel) y las especies menores de la cilla canóniga (avena, lentejas, garbanzos, yeros, titos y mosto) ${ }^{24}$.

Los mercados semanales y ferias anuales organizados en Palencia a lo largo de la Edad Moderna permitían la distribución y comercialización de muchos géneros alimenticios. La capital celebraba su mercado todos los jueves del año, por real privilegio otorgado en 1529 por los reyes Carlos I y Juana $\mathrm{I}^{25}$. A este encuentro concurrían vecinos de toda la comarca con trigo, cebada y ganados de cerda ${ }^{26}$. Destacaba también la feria de septiembre, en honor al patrón de la ciudad, san Antolín, donde "se venden y truecan vorricos, pollinas, jumentos, jumentas y otras vestias y cerdos", generalizando, por otra parte, el consumo de embutidos, lo que hizo de diciembre el mes más idóneo para que "por todos sus días, concurra ganado vacuno a venderse para zezinas ${ }^{27}$.

22. Planta herbácea medicinal que se utiliza en la elaboración de ciertas bebidas alcohólicas, como el licor de ajenjo, la absenta o el vermut.

23. Parcero Torre, Celia y GonzÁlez Lázaro, Ángel. "La relación de poderes en Palencia a mediados del siglo XVII». En Actas del III Congreso de Historia de Palencia, vol. III. Palencia: Diputación Provincial, 1995, p. 97

24. ACP, Contaduría, Cuentas generales de Fábrica, libro 932, año 1788. Libro mayor de cuentas de la Mesa capitular y Fábrica, n. ${ }^{\circ} 885$, año 1700.

25. Marcos Martín, Alberto. Economía, sociedad y pobreza en Castilla: Palencia, 1500-1814. Palencia: Diputación Provincial, 1985, p. 71.

26. Larruga Boneta, Eugenio. Memorias políticas y económicas sobre los frutos, comercio, fábricas y minas de España, provincia de Palencia, tomo XXXII. Madrid: por don Antonio Espinosa, 1794, pp. 283-284.

27. AMP, Administración, Patrimonio, Libro inventario de propiedades de la ciudad de Palencia, 1751, caja 132, f. 20 r. 
Aunque gran parte de los alimentos citados anteriormente no estaban al alcance de la población, muchos fueron consumidos en los banquetes y colaciones de los innumerables acontecimientos festivos que Palencia albergó a finales del Antiguo Régimen. A esto debemos añadir las visitas de monarcas y destacadas personalidades del ámbito eclesiástico y militar, pues su presencia solía llevar aparejado un agasajo "con abundancia de esquisitos manjares y de selectas bebidas» ${ }^{28}$, como ocurrió, por ejemplo, con la visita de Fernando VII y María Josefa Amalia de Sajonia a Palencia en 1828.

\subsection{La comida: un elemento más para engrandecer la fiesta}

La creciente demanda de algunos comestibles originada por el arribo de forasteros a la ciudad los días de una celebración festiva solía generar a veces ciertos problemas en el abastecimiento de víveres, por lo que el Ayuntamiento debía garantizar su distribución, «especialmente aquellos que son de primera necesidad» ${ }^{29}$, como el pan, el alimento básico de la dieta de la población del Antiguo Régimen. Pero la calidad no era la misma para ricos y pobres, pues mientras que para los primeros se destinaba el pan blanco, para los segundos solo había pan moreno (integral). Así, por ejemplo, en la mesa de estado ofrecida a José Bonaparte en su visita a Palencia en 1811 encontramos las siguientes cantidades y clases: 25 panes, varios panes grandes, 12 panes franceses y numerosos panecillos.

En cuanto al pescado, siempre más escaso como hemos visto, podemos señalar que en Palencia existen pocas referencias en los momentos festivos de este periodo. La primera aparece en 1746 en la celebración por la canonización de san Pedro Regalado ${ }^{30}$, donde el autor de la dedicatoria del sermón recibió como obsequio seis libras y media de besugo por importe de 22 reales ${ }^{31}$. También hallamos un plato de pescado en el almuerzo brindado al hermano de Napoleón, aunque la documentación no especifica el género. Por último, destaca la existencia de lubinas, salmones, langostas y anguilas ${ }^{32}$ en uno de los banquetes de Fernando VII

28. Gómez De Robledo, Juan Antonio. Venida de los SS. Reyes a Palencia y mansión en ella. Año de 1828. Relación individual y diario histórico de las funciones hechas por la I. N. y L. ciudad de Palencia, para el recivimiento de SS.MM. con las demás ocurrencias, durante su detención y permanencia en ella. [Palencia], 1828, f. 10r.

29. AMP, Actas Municipales, 28/03/1789, f. 87r.

30. EGIDO López, Teófanes. "La religiosidad colectiva de los vallisoletanos». En ENCISO RECIO, Luis Miguel et al. Valladolid en el siglo XVIII. Valladolid: Ateneo de Valladolid, 1984, pp. 193-199. También del mismo autor en: "Formas de religiosidad en la época moderna". En Valladolid. Historia de una ciudad (época moderna). Valladolid: Ayuntamiento de Valladolid, 1999, vol. 2, p. 516.

31. AMP, Servicios, Cultura, Festejos, Expedientes de gastos, 1748, caja 291, leg. 6, s. f.

32. SÁnchez García, José Luis. "La herencia de la Ilustración». En García Colmenares, Pablo; Moreno Lázaro, Javier y Sánchez García, José Luis (coords.). Historia de Palencia. Siglos XIX-XX. Palencia: El Norte de Castilla, 1996, p. 12. 
y su esposa en julio de 1828, donde el prestigio de los comensales viene determinado por la calidad de los peces y el marisco ${ }^{33}$.

Sucede lo contrario en el caso de la volatería y la carne asada, pues su presencia en los festines solía ser muy abundante, especialmente durante las visitas y estancias de los monarcas. A menudo estas jornadas se caracterizaban por una copiosísima mesa de estado provista de ricas viandas acompañadas de legumbres, verduras y hortalizas.

En el menú elaborado para agasajar a José I y su séquito en 1811 encontramos el tradicional cocido compuesto por garbanzos, ternera, pollo y gallina, tocino fresco y berza, así como un plato principal de carne (lechazo y carnero), pan, queso y cebollas, manadas de espárragos, lechugas y rábanos, todo ello aderezado con aceite de Provenza, vinagre y algunas especias (clavo y pimienta). Solo el coste del banquete, sumado al de la bebida y los dulces, alcanzó los 6.286 reales, lo que supone el 80 \% del total destinado a la visita real, incluyendo la materia prima, el importe de la elaboración de los platos y el salario de los cocineros, pasteleros, cazadores, cabestreros y pescadores ${ }^{34}$.

La llegada también en 1811 a Palencia del general Dorsenne, comandante en jefe del Ejército del Norte, que sustituía al mariscal Bessières en el cargo, dejó tras de sí un espléndido banquete que contenía dieciséis pichones, ocho gallinas, dos pollos, una liebre, 34 libras de carnero, dos empanadas de palomino y quince empanadillas, valorado todo ello en 677 reales $^{35}$.

La mesa de un día cualquiera (1828) de los reyes Fernando VII y María Josefa Amalia de Sajonia estaba formada por garbanzos, seis libras de vaca, seis de costillas de carnero, una pierna de ternera, ocho pollas, seis pollos, cuatro pichones, un pavito y cuatro perdices. Disponemos únicamente de las cantidades totales de tres productos consumidos durante los cinco días que permanecieron los monarcas: dos fanegas y tres celemines de garbanzos (324 reales), diez arrobas y dieciocho libras y media de aceite ( 472 reales) y 493 arrobas de nieve (3.499 reales), lo que nos da una idea de la enorme inversión que hacía el municipio en alimentación, pues el $33 \%$ del gasto relativo a la estancia del rey corresponde al acondicionamiento del aposento, manutención de los monarcas, salarios de cocineros y coste de los productos y manjares adquiridos para su mesa, sin olvidar el

33. Resulta interesante completar el aspecto de la alimentación del rey en la corte con los trabajos de PÉrez SAmper, María Ángeles. "La mesa real en la corte borbónica española del siglo XVIII". En Torrione, Margarita (ed.). España festejante: el siglo XVIII. Málaga: Diputación de Málaga, 2000, pp. 205-218; "La alimentación en la corte española del siglo XVIII". Cuadernos de Historia Moderna, 2003, Anejo 2, pp. 153-197.

34. Razón del gasto hecho por la venida del rey José I Bonaparte. AMP, Hacienda, Bienes y cuentas de Propios y Arbitrios, 1811, caja 544, leg. 2. También en Actas Municipales, 22/07/1811, ff. 337r.-340r. El restante $20 \%$ del total del gasto corresponde a fuegos artificiales, iluminación, festejos y arquitectura efímera, como adornos y arcos triunfales.

35. AMP, Actas Municipales, 19/07/1811, ff. 340r.-341r. 
sustento de los animales que componían el séquito, especialmente las caballerías, ya que fueron necesarias 41 fanegas y seis celemines (2.287 kilos aproximadamente) de cebada ${ }^{36}$.

El festejo del aniversario de la Constitución de Cádiz celebrado en Palencia en 1821, tras ser restaurada durante el Trienio Liberal, contó con un almuerzo para agasajar a algunos militares y diversas personas distinguidas, pues se trataba de una de "las funciones más solemnes, sagradas y patrióticas ${ }^{37}$ de la época. Las mesas fueron preparadas en el centro de la Plaza Mayor para dar cabida a los 240 comensales. Las cantidades quedaron fijadas en una libra de vianda y medio pan por persona. El menú consistió en sopa, dos ollas provistas de vaca, carnero, tocino, garbanzos y verdura, dos platos principales de ternera o cordero, queso y fruta de postre ${ }^{38}$.

El postre de cualquier festín solía estar compuesto por frutas, quesos, helados y confituras. El variadísimo surtido de dulces tradicionales contaba con algunos ingredientes fundamentales para su elaboración: huevos, manteca de cerdo, almendras, leche, azúcar y canela, aunque a veces se empleaba carne para una sabrosa variedad de pastel, el manjar blanco, una especie de guisado muy apreciado que se hacía con harina de arroz, pechuga de gallina cocida, leche y azúcar ${ }^{39}$.

La documentación del dominio napoleónico en Palencia recoge los nombres de los dulces y el número de unidades que se consumieron en el banquete servido a José Bonaparte: diez medias fuentes de leche aderezada, cuatro medias fuentes de huevos hilados y la misma cantidad de huevos moles, tres tartas de leche, dos de almendra, una tarta grande guarnecida con ramos y leones, y otras dos medianas, cincuenta empanadillas de dulce de leche, dos docenas y media de cubiletes (una especie de pastel redondo relleno de carne picada), cuatro docenas y media de dulces de canela, varios quesos helados, bizcochos de pan, frutas confitadas, caramelos y grageas, alubias y almendras de garapiña. En su elaboración se emplearon cerca de treinta docenas de huevos, ocho onzas de canela fina y siete libras de almendras.

En el almuerzo servido al general Dorsenne en el verano de 1811 encontramos también algunas cantidades de los productos que se emplearon para componer los dulces: seis libras de manteca, cuatro libras de azúcar blanca, dos libras de almendras, 50 huevos y una libra de chocolate, además de las 18 libras de fruta de temporada (cerezas y albérchigos ${ }^{40}$ ).

36. Cuaderno para la toma de razón de los fondos para los gastos de la visita de SS.MM. Expediente sobre la visita real a Palencia. AMP, Gobierno, Expedientes, 1828, caja 44, leg. 5.

37. AMP, Actas Municipales, 23/03/1821, f. 121r.

38. AMP, Actas Municipales, 12/03/1821, f. 112r.

39. RAE, Diccionario de Autoridades, tomo IV, 1734, vOz «manjar blanco».

40. «Especie de melocotón; fruta de hueso de las últimas que maduran, y de las más sabrosas. Su carne es recia, xugosa, y de color amarillo mui subido, especialmente la que más se acerca al hueso, que suele tocar en roxo". RAE, Diccionario de Autoridades, tomo I, 1726, voz "albérchigo». 
Los «refrescos» dispuestos en la celebración de la onomástica del monarca francés, cada 19 de marzo, también contenían diversos dulces, como mantecadas, empanadillas, pastas y bizcochos. El consumo de estos últimos estaba muy extendido entre los estamentos privilegiados, pues se comían habitualmente con el chocolate caliente. En la colación de exequias de Felipe V en 1746 se precisaron ocho libras de este confite elaborado con harina, huevos y azúcar, mientras que en la proclamación de Carlos III en 1759 se sirvieron "delicados bizcochos de diferentes géneros ${ }^{41}$. Los había largos, redondos, cuadrados, unos sin baño y otros bañados de azúcar y canela. La variedad de garapiña era una de las más apreciadas, pues estos eran "de mucha más suavidad y delicadeza que los ordinarios» ${ }^{42}$. En 1823, en la fiesta por el regreso al trono de Fernando VII y el restablecimiento del absolutismo tras la intervención militar extranjera, también se comieron «algunos bizcochos sueltos".

Mención especial merecen dos de los productos ultramarinos más apreciados en el siglo XVIII por los castellanos: el azúcar y el cacao. Algunos adinerados mercaderes palentinos, como Bernardo de la Rosa y Lorenzo Sanz Córdoba (17021764), además de tener «lonja de jéneros de mercadería, como paños y telas de distintas clases", se dedicaron al comercio activo americano de "cacao, azúcar y otros surtidos ${ }^{43}$.

El azúcar fue uno de los productos más importantes de la cocina en la centuria ilustrada, pues se utilizaba frecuentemente para endulzar diversos alimentos. Fue uno de los llamados productos de ida y vuelta, que del Viejo Mundo fue llevado al Nuevo y después volvió al Viejo. Su presencia se puede encontrar en casi todas las bebidas refrigeradas (sorbetes, limonada, naranjada, agua de frutas, bebidas alcohólicas), pero también en el chocolate caliente, los helados y en cualquier dulce o confitura. El mercader Lorenzo Sanz fue un importante proveedor de azúcar blanca del Concejo en los años finales del reinado de Fernando VI y primeros de Carlos III, tendencia que se repite sistemáticamente con ocasión de la festividad anual del Corpus ${ }^{44}$. Por citar un par de ejemplos, diremos que en 1755 suministró 570 libras por valor de 1.824 reales, y siete años más tarde advertimos

41. El mejor día del año, fin de miserias, y principio de felicidades para la lealtad y para el amor de los palentinos: el solemne, festivo y venturoso día XV de octubre de MDCCLIX, en que la muy noble y muy leal ciudad de Palencia hizo la gloriosa aclamación de nuestro catbólico rey y señor Carlos Tercero (que Dios guarde). Valladolid: Imprenta de Alonso del Riego, [1759], p. 50. Los refrescos de proclamación fueron habituales en otras ciudades cercanas, como Valladolid: TORREMOCHA HERNÁNDEZ, Margarita. "Diversiones y fiestas en Valladolid durante el Antiguo Régimen». En Valladolid. Historia de una ciudad (época moderna). Valladolid: Ayuntamiento de Valladolid, 1999, vol. 2, p. 506.

42. RAE, Diccionario de Autoridades, tomo IV, 1734, vOZ "garapiña".

43. AHPP, Protocolos notariales, Mateo Guerra, leg. 6966, f. 363r. Sobre la figura de este mercader puede verse QujJada ÁlAmo, Diego. «Lorenzo Sanz y Córdoba, un hombre de negocios con afición a los libros. La biblioteca de un mercader castellano (1764)». Tiempos Modernos, 2018, 37, 2, pp. 52-78.

44. Sobre la fiesta del Corpus Christi pueden verse algunas reflexiones: REDER GADOw, Marion. "Tradición e innovación en la procesión del Corpus Christi malagueña en la época de los Borbones". 
el encarecimiento de este producto, pues la cantidad fue esta vez de 18 arrobas y veinte libras (en total 470 libras, es decir, cien libras menos), y su coste, sin embargo, había ascendido a los 1.880 reales $^{45}$. Pero estas cantidades de azúcar no se destinaban para preparar el «refresco», sino que se repartían entre los regidores y cargos municipales que asistían a la función en concepto de propina para su consumo particular, como ocurrió también en la fiesta del Corpus de $1741^{46}$.

Pero el producto estrella de la época fue el cacao. Su grano era una "fruta menor que la almendra, aunque más gruesa y redonda; la cáscara delicada, algo fría y húmeda, que tostada y molida es el principal material para fabricar el chocolate ${ }^{47}$. Su comercialización en Palencia se debió, en gran medida, al mercader Bernardo de la Rosa, a quien el Concejo concedió en 1751 los derechos de entrada del cacao venezolano a través de la Real Compañía Guipuzcoana de Caracas. Meses después era aprobada la cuenta de los noventa quintales (más de cuatro mil kilos) de cacao traídos desde San Sebastián a Palencia para el consumo de particulares $^{48}$. El desasosiego creado en 1762 ante el desabastecimiento que sufrieron las ciudades españolas pone de manifiesto el alto valor de este preciado y exótico alimento ultramarino:

[...] se esperaba un nabío que deviera haver llegado cargado de cacao [...]. Los almacenes de Cádiz, San Sebastián i aun este se hallan sin disposición alguna para socorrer a los muchos que del Reino acuden por dicho género, estando con gran desconsuelo del retardo del nominado navío, teniendo como ia corren voces de que se a apresado por los ingleses, una falta que yo lo siento infinito ${ }^{49}$.

Por otro lado, el chocolate fue el presente al que con mayor asiduidad acudió el Ayuntamiento de Palencia para recompensar a los predicadores del sermón en las jornadas festivas, como ocurrió en la celebración por la canonización de san Pedro Regalado (1746), donde el canónigo penitenciario, Juan Luelmo Pinto, fue agasajado con media arroba de chocolate.

En Torrione, Margarita (ed.). España festejante: el siglo XVIII. Málaga: Diputación de Málaga, 2000, pp. 63-73; SÁnchez Carrasco, Antonio. El Corpus de Sevilla. Córdoba: Almuzara, 2019.

45. La libra de azúcar pasó de valer 3,2 reales en 1755 a 4 reales en 1762, siendo invariable su precio, al menos, hasta 1804. AMP, Actas Municipales, 08/07/1755, f. 148r.; 09/07/1762, ff. 67v.-68r.; 24/05/1804, ff. 183v.-184r.

46. AMP, Servicios, Cultura, Festejos, Expedientes de gastos, 1741, caja 291, leg. 3.

47. RAE, Diccionario de Autoridades, tomo II, 1729, voz "cacao". Sobre el chocolate puede verse: Drumond Braga, Isabel. "O chocolate à mesa: sociabilidade, luxo e exotismo». En Formas e espaços de sociabilidade. Contributos para uma História da Cultura em Portugal. Lisboa: Universidade Aberta, 2008, pp. 1-17; PÉREZ SAMPER, María Ángeles. «El chocolate en la España moderna: negocio y placer». En Franco RuBIO, Gloria (coord.). Caleidoscopio de la vida cotidiana (siglos XVI-XVIII). Logroño: Editorial Siníndice, 2016, pp. 61-95.

48. AMP, Actas Municipales, 27/02/1751, f. 44r.; 17/03/1751, f. 61r.

49. Carta de Antonio Tovar al ayuntamiento de Palencia, Madrid, 28/04/1762. AMP, Actas Municipales, 07/05/1762, f. 42r. y v. 
Más habitual fue la predicación con motivo de las exequias de los reyes y reinas, pues la elaboración del sermón fúnebre también estaba recompensada con idéntica cantidad de chocolate labrado ${ }^{50}$. Los memoriales de gasto revelan que la gratificación solía incluir además unos pañuelos de seda y cuatro libras de tabaco repartidas en dos botes. Así lo señala también el padre Isla en su famosa obra Fray Gerundio de Campazas (1758), ya que en la celda de un buen predicador nunca podía faltar «un polvo de buen tabaco, una jícara de chocolate [y] un par de mudas de ropa blanca ${ }^{51}$. Sin embargo, a veces se podía recurrir a otros productos exóticos como el cacao en bruto o la canela ${ }^{52}$.

Desde el funeral de María Luisa Gabriela de Saboya (1714) hasta el de María Josefa Amalia de Sajonia (1829) el chocolate permaneció de forma inalterable en Palencia como parte esencial del obsequio a los miembros del Cabildo. La única salvedad la encontramos a inicios del siglo XIX al detectar una modificación, ya que la media arroba pasa a denominarse "molienda de chocolate», haciendo alusión al trozo o porción, y no a la cantidad.

El consumo de este producto llegó a convertirse en un auténtico vicio muy extendido entre el clero capitular, hasta el punto de que se comía sin ningún pudor en la sacristía o en las recapillas de la catedral. Esta irreverencia alcanzó su punto más álgido en 1789, cuando una criada fue sorprendida al término de la misa oficiada por un capellán en el instante en el que le llevaba chocolate a escondidas. A raíz del acontecimiento, se impuso una multa de dos ducados a los transgresores que en adelante infringieran esta norma, ya fuesen dignidades, canónigos, capellanes o racioneros ${ }^{53}$.

\subsection{La bebida indispensable en los días de fiesta}

La bebida en las sociedades modernas formaba parte indispensable de la vertiente lúdica y recreativa de las celebraciones, de los almuerzos y banquetes, de los «refrescos» y meriendas, que organizaban las autoridades urbanas con cualquier pretexto festivo. Especialmente esta era necesaria como acompañamiento de la comida o para aplacar el calor de las largas tardes estivales. Por esta razón, el

50. El coste de media arroba de chocolate también osciló en Palencia, pues en 1714 fue de 94 reales; en 1746, de 87 reales y medio, y en 1759, de 112 reales y medio. AMP, Hacienda, Bienes y cuentas de Propios y Arbitrios, 1714, caja 519, leg. 8; 1746, caja 533, leg. 11; Actas Municipales, 22/12/1759, ff. 219v.-220r.

51. IsLA, José Francisco de. Historia del famoso predicador fray Gerundio de Campazas, alias Zotes (Madrid, 1758). Barcelona: Planeta, 1991, vol. I, p. 174.

52. Esta práctica también se introdujo tardíamente en Burgos, pues no se detecta hasta 1696, año en que el predicador fue obsequiado con una arroba de chocolate. Melgosa Oter, Óscar Raúl. "Protagonistas en las exequias de los Austrias: los predicadores del sermón fúnebre». Obradoiro de Historia Moderna, 2007, 16, p. 280.

53. ACP, Acuerdos Capitulares, 05/03/1789, f. 38r. 
Ayuntamiento solía conceder licencias de venta al público a los comerciantes de bebidas refrigeradas con el fin de tener provista la ciudad "del surtido necesario de vevidas heladas en la hépoca más tórrida de la estación ${ }^{54}$, sobre todo cuando algún evento festivo estaba a punto de acontecer.

Además de bebidas, los botilleres vendían también helados en sus establecimientos, aunque no como los conocemos hoy en día. A modo de ejemplo en Palencia, puede servir el "experimento físico» de una receta de helado de agua de limón llevado a cabo en mayo de 1804 en el recibidor de la sala capitular del ayuntamiento, donde "se hizo comparecer a Fernando Badillo, de esta vecindad, y repostero en el Real Palacio, inteligente por esta razón en la composición de

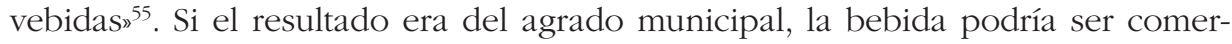
cializada en la ciudad. En origen, fueron precisos los siguientes ingredientes para su elaboración: media cántara de agua, dos libras de azúcar blanca, tres limones murcianos, medio cuartillo de sal y ocho libras de nieve. No obstante, el experto señaló que la bebida debía permanecer helada largo tiempo en las botillerías antes de su consumo, por lo que eran necesarias ocho libras más de nieve ${ }^{56}$. Los allí presentes degustaron el producto final y admiraron la "perfección» $\mathrm{y}$ "delicadeza» de su sabor, quedando muy "satisfechos de la bondad y superior calidad de la vebida ${ }^{57}$.

A lo largo del siglo XVIII la documentación palentina indica que las bebidas más consumidas por las élites en los días festivos fueron la limonada y el chocolate. Se trataba, sobre todo esta última, de una de las "bebidas de sociabilidad" por excelencia de la España ilustrada ${ }^{58}$. Así lo advertimos, por ejemplo, en 1712, en los festejos taurinos tras el nacimiento del infante Felipe Pedro de Borbón, «no dando más que una bevida y chocolate a los señores del regimiento ${ }^{59}$, o en 1725 , con motivo de la fiesta organizada por la firma del tratado de paz entre España y el Imperio alemán, donde se tomaron sorbetes de limón y, después, chocolate caliente combinado con canela y azúcar, y algunas especias (pimienta, clavo, jengibre), que daba como resultado una bebida muy dulce, espesa, aromática y fuertemente especiada ${ }^{60}$. También se observa en el «refresco» que preparó el Ayuntamiento a sus invitados en 1746 con motivo de la celebración de las honras fúnebres de Felipe V, siendo necesarias para su composición tres cántaras y media de agua

54. AMP, Actas Municipales, 05/07/1828, f. 301v.

55. AMP, Actas Municipales, 24/05/1804, ff. 183v.-184r.

56. El coste total de los ingredientes fue de 22 reales y 6 maravedís, siendo su desglose: azúcar blanca ( 8 reales), limones murcianos ( 4 reales y 8 maravedís), sal (18 maravedís) y nieve ( 9 reales y 14 maravedís).

57. AMP, Actas Municipales, 24/05/1804, f. 184r. y v.

58. PÉREZ SAMPER, María Ángeles. "Espacios y prácticas de sociabilidad en el siglo XVIII: tertulias, refrescos y cafés de Barcelona». Cuadernos de Historia Moderna, 2001, 26, pp. 11-55.

59. AMP, Actas Municipales, 10/06/1712, f. 58r. y v.

60. PÉrez SAMPer, María Ángeles. "El chocolate...», op. cit., p. 69. 
de limón, veintidós libras de azúcar, cuarenta y cinco limones y cuatro libras de chocolate. Su coste final, sumado al de los bizcochos, fue de 142 reales $^{61}$.

La limonada y el chocolate siguieron formando parte del consumo habitual de la fiesta en el tránsito del Antiguo Régimen al liberalismo, pues su presencia se detecta en las fuentes palentinas en 1789 (proclamación de Carlos IV) y 1812 (publicación y juramento de la Constitución de Cádiz), donde se ofreció a los regidores «un refresco de dos bebidas y chocolate». Incluso en 1823, con ocasión de la celebración del regreso al trono de Fernando VII y el retorno del absolutismo, algunos invitados pudieron saborear un vasito de limonada fresca procedente de la cántara y media (24 litros) que con gran esmero prepararon Juan y Francisco Argumosa, botilleres de la ciudad.

En el siglo XIX, especialmente en los ambigús ${ }^{62}$ de la etapa napoleónica (1808-1813), se detecta la presencia de otras bebidas muy apreciadas como el café, que se introduce y generaliza en esta época en las sobremesas de los grandes banquetes, y el ponche, una bebida hecha a base de aguardiente templado, agua, limón y azúcar, que servía de acompañamiento a los dulces y confituras.

Pero, sin duda, la bebida por excelencia más consumida en las sociedades del Antiguo Régimen fue el vino, aunque generalmente se reservaba para las fiestas. Los vinos palentinos, "aunque algo cubiertos, son de buen color, sabor, muy estomacales y nada cabezudos" ${ }^{63}$, señalaba en 1803 el afamado cirujano Agustín Argüello. El vino durante la Edad Moderna fue un artículo de consumo que estaba sujeto al pago de impuestos. El Ayuntamiento de Palencia tenía por concesión real la facultad de imponer 39 maravedís en cada cántara de vino tinto y 17 en cada cántara de vino blanco que se cosechara o introdujera en la ciudad para el consumo de los particulares (volandero) o se vendiera en la tabernilla ${ }^{64}$.

Esta bebida podemos encontrarla de forma recurrente en las proclamaciones reales, es decir, los acontecimientos políticos más importantes para la monarquía -se resolvía la cuestión sucesoria y se garantizaba la estabilidad del reino-, pero también para las ciudades, pues todas tenían la obligación de festejar este acto.

61. La relación de todos los gastos pormenorizados en las exequias de Felipe V en Palencia puede constatarse en AMP, Hacienda, Bienes y cuentas de Propios y Arbitrios, 1746, caja 533, legs. 11 y 12, s. f. y en Libros de cuentas de Propios y Arbitrios, 1747, caja 570, libro 1, s. f.

62. El ambigú es un bufé compuesto de platos fríos y calientes (entremeses, verduras, carnes, pescados o postres) y algunas bebidas de manera que los comensales pueden escoger y servirse ellos mismos.

63. Argüello Castrillo, Agustín. Dictamen físico-médico..., op. cit., p. 6.

64. Marcos MarTín, Alberto. "Palencia en el siglo XVIII». En GonZÁlez GonZÁlez, Julio (coord.). Historia de Palencia. Palencia: Diputación Provincial, 1995, vol. 2, p. 122, nota n. ${ }^{\circ} 57$. AMP, Actas Municipales, 15/01/1790, f. 23v. Especialmente sobre el vino volandero y de acarreo puede verse el acta de 06/02/1789. También, SAn MarTín PAYO, Jesús. "La Real Sociedad Económica de Amigos del País de Palencia”. Publicaciones de la Institución Tello Téllez de Meneses, 1982, 46, pp. 232-233. Sobre el vino en Palencia para la época moderna: Herrero Martínez DE AzCoitia, Guillermo. «El vino en Palencia en los siglos XV, XVI y XVII». Publicaciones de la Institución Tello Téllez de Meneses, 1958, 17, pp. 17-41. 
Palencia contó con seis celebraciones a lo largo del siglo XVIII y primer tercio del XIX, una por cada monarca: Felipe V, Luis I, Fernando VI, Carlos III, Carlos IV, Fernando VII e Isabel II.

En ellas, el momento más esperado, acabadas las solemnes ceremonias, era la llegada de la fiesta y el regocijo. El alférez mayor, el encargado de levantar el estandarte regio y una de las figuras más destacadas de estas celebraciones, organizaba un "refresco" para las personas más distinguidas de la sociedad, aunque el estamento popular también se beneficiaba de estos actos, pues para ellos se mandaba edificar una "fuente de buen vino" que sirviera "de refrigerio al apetito de los sedientos ${ }^{65}$. Esta construcción solía instalarse al pie de la casa del anfitrión, con arcos adornados de ramos de hiedra, de la que «manaba todo el día delicado néctar ${ }^{66}$. La desmesurada asistencia ante algo gratuito provocaba el agolpamiento de la gente, que se abría paso a codazos con la intención de llegar al pilón. No fueron pocos -señala la literatura festiva de la época- los que "recogían el vino en los casquetes de los sombreros porque los jarros y botijas se hicieron cascos ${ }^{67}$. Las consecuencias derivadas de la ingesta masiva de aquella bebida alcohólica se dejaron sentir entre la población ${ }^{68}$, pues muchos afirmaban que su consumo en exceso "daba luces multiplicadas a los ojos" ${ }^{69}$, llegando a ver doble. Sin embargo, "los más versados [...] [decían] que durmiendo bien, volberían los ojos a lo antiguo ${ }^{{ }^{70}}$. A fin de cuentas, una borrachera no dejaba de ser algo "pasajero".

Las proclamaciones reales también solían contar con un "refresco» costeado por el Concejo, del que podían beneficiarse algunos oficios que hubieran participado en la organización de los festejos. A modo de ejemplo sirva la ceremonia de aclamación de Luis I en 1724, en la que la corporación municipal repartió nada menos que 245 cántaras (3.920 litros) de vino entre los gremios textiles y los soldados del batallón de Inválidos, cuyo importe ascendió a 2.427 reales, representando un $20 \%$ del coste total ${ }^{71}$.

El vino, por otra parte, también era una bebida muy consumida por las oligarquías en acontecimientos muy señalados, como la visita de los reyes o algunas personalidades de la jerarquía militar. Así, en el banquete ofrecido a José

65. AMP, Actas Municipales, 25/09/1746, f. $187 \mathrm{v}$.

66. El mejor día del año, fin de miserias..., op. cit., pp. 39-40.

67. El mejor día del año, fin de miserias..., op. cit., p. 40.

68. Los problemas de alcoholismo fueron frecuentes a finales del Antiguo Régimen entre la población con menos recursos, especialmente en las clases obreras en el siglo XIX. PRADO ANTÚNEZ, Ana Isabel. "Fiestas, romerías...», op. cit., pp. 63-64.

69. La lealtad en extremo y el festejo hasta su esfera: lo más que se pudo hacer y decir en la $M$. N. y antigua ciudad de Palencia en la solemne proclamación de nuestro católico rey y señor don Carlos IV (que Dios guarde). Palencia: Oficina de Francisco Xavier Riesgo y Gonzalorena, [1789], p. 52. RBME, Salón principal, Monografías antiguas, signatura: 44-V-23 $\left(2 .^{\circ}\right)$.

70. La lealtad en extremo..., op. cit., pp. 52-53.

71. Cuenta de los gastos de la proclamación de Luis I. AMP, Hacienda, Bienes y cuentas de Propios y Arbitrios, 1724, caja 525, leg. 5. 
Bonaparte en 1811 se bebieron algo más de cien litros ( 404 reales) repartidos en tres cántaras de vino tinto común, otras tres de vino de Aragón y cuatro botellas de vino de Málaga. Por aquellas fechas se agasajó también con dos cántaras y media (40 litros) de vino de Aragón y seis botellas de vino selecto a los comensales del almuerzo celebrado en homenaje del general Dorsenne. Aunque no conocemos la cantidad exacta de vino de Valdepeñas consumido en la mesa de estado ofrecida a Fernando VII y su séquito en 1828, podemos señalar que fueron varios cientos de litros, dada su larga permanencia en la ciudad (cinco días) y el alto coste de esta partida (3.450 reales).

La celebración de festejos reales en la década de los años veinte del siglo XIX nos permite ver la diferenciación del consumo de esta bebida según su calidad. Así, durante la comida organizada para los oficiales y tropa en el aniversario de la Constitución de Cádiz (1821) se sirvió abundante vino tinto corriente, dejando el más selecto, el de la variedad de Peralta ${ }^{72}$, para los postres. En cambio, en las fiestas de 1823 se dio vino blanco a la guardia de la milicia del batallón de voluntarios realistas en agradecimiento a su labor de custodiar el retrato real.

En ocasiones, también se consumían otras bebidas alcohólicas elaboradas con zumo de uva fermentado, como la clarea, una bebida hecha con vino blanco, miel, canela y otras especies aromáticas ${ }^{73}$, que aparece en la documentación en 1823. Por el contrario, no encontramos rastro alguno de cerveza en las fiestas y eventos sociales, pues su consumo en España durante la Edad Moderna era muy reducido y solía ser de mala calidad.

\section{LA DIMENSIÓN ASISTENCIAL DE LA FIESTA}

Las ciudades en el Antiguo Régimen, como señala Alberto Corada, "fueron capaces de ofertar asistencia [...] gracias a las transferencias de rentas en forma de limosnas que se daban para esos pobres que eran la imagen de Cristo en la Tierra ${ }^{74}$. El sistema de caridad urbano en el Antiguo Régimen estaba configurado en buena medida por diversas instituciones y corporaciones, como las cofradías, los hospitales, los pósitos y las fundaciones piadosas, encargadas de organizar y encauzar la asistencia de los sectores más desfavorecidos de la sociedad ${ }^{75}$ : huérfanos, pobres, enfermos, viudas, doncellas sin dote, estudiantes, etc.

72. Vino de fama nacional, muy extendido en el siglo XIX en España.

73. RAE, Diccionario de Autoridades, tomo II, 1729, vOZ "clarea».

74. Corada Alonso, Alberto. Un beaterio en la Castilla del siglo XVIII: Vida y muerte en San Lázaro de Aguilar de Campoo. Palencia: Institución Tello Téllez de Meneses, 2015, p. 28.

75. Algunos trabajos indispensables sobre la pobreza y la asistencia son los de MAZA ZORRILLA, Elena. Valladolid: sus pobres y la respuesta institucional (1750-1900). Valladolid: Junta de Castilla y León, 1985; Pobreza y asistencia social en España (siglos XVI-XX): aproximación histórica. Valladolid: Universidad de Valladolid, 1987; MARCos MarTín, Alberto. Economía, sociedad y pobreza en Castilla: Palencia, 1500-1814. Palencia: Diputación Provincial, 1985; PaLomares IBáÑEZ, Jesús María. 
El Catastro del Marqués de la Ensenada señala que a mediados del siglo XVIII Palencia albergaba más de 500 pobres de solemnidad, «que viven de las limosnas que les franquean los conventos y vecinos que pueden de esta ciudad ${ }^{76}$, lo que supone el 19,8 \% de una población que, por aquel entonces, contaba con 2.518 vecinos $^{77}$. Si bien es cierto que estas cifras, poco representativas, excluían a un buen número de habitantes, ya que los datos únicamente se referían a aquellos cuyo estado era de miseria absoluta.

Palencia contaba con diversas cofradías conventuales que ofrecían asistencia espiritual y material ${ }^{78}$, así como dos hospitales para el cuidado de pobres, niños expósitos y enfermos, donde se les procuraba "cama, razión, medizinas, médico, cirujano, y quanto necesitan ${ }^{79}$ : el de san Antolín y san Bernabé, dependiente del Cabildo de la catedral y dotado con una renta anual -decía Ponz- que "pasa de veinte y dos mil ducados ${ }^{80}$, y el de san Blas, regentado por la orden hospitalaria de San Juan de Dios, aunque su patronato pertenecía al Ayuntamiento ${ }^{81}$.

Existían además en la ciudad numerosas obras pías ${ }^{82}$, es decir, fundaciones que implicaban la donación de un capital destinado a favorecer a una población sin recursos (pobres, enfermos, doncellas huérfanas), con una orientación caritativa, pero también religiosa, pues allanaba el camino a la salvación de aquellos que las instituían. Así, siguiendo las enseñanzas evangélicas ${ }^{83}$, cada obra pía «realizaba una función social específica de acuerdo con la voluntad expresada por

La asistencia social en Valladolid: el Hospicio de pobres y la Real Casa de Misericordia (1724-1847). Valladolid: Diputación Provincial, 1975; RHeInHeImer, Martin. Pobres, mendigos y vagabundos: la supervivencia en la necesidad (1450-1850). Madrid: Siglo XXI, 2009.

76. AMP, Administración, Patrimonio, Libro inventario de propiedades de la ciudad de Palencia, 1751, caja 132, f. 40r.

77. Marcos Martín, Alberto. Economía, sociedad..., op. cit., p. 376.

78. LOZANO RUIZ, Carlos. "Caridad y asociacionismo religioso conventual en Palencia durante la Edad Moderna (ss. XVI-XVIII)». En SERRANO MARTín, Eliseo (coord.). De la tierra al cielo: líneas recientes de investigación en historia moderna. Zaragoza: Fundación Española de Historia Moderna, Institución Fernando el Católico, 2012, pp. 85-100.

79. AMP, Administración, Patrimonio, Libro inventario de propiedades de la ciudad de Palencia, 1751, caja 132, f. 20v.

80. POnz PiQuer, Antonio. Viage de España, en que se da noticia de las cosas más apreciables y dignas de saberse, que hay en ella. Madrid: impresor Joaquín Ibarra, 1783, tomo XI, p. 152.

81. Algunos estudios de hospitales de localidades cercanas: PÉrEz ÁLvAREZ, María José. "Enfermedad y caridad en la provincia de León durante la Edad Moderna: el hospital de las Cinco Llagas de la ciudad de Astorga». Hispania Sacra, 2011, LXIII, 127, pp. 75-102; MARTín GARCía, Alfredo. "Pobres y enfermos en el León de la Edad Moderna: la asistencia hospitalaria en la ciudad de Astorga». En RUBIO PÉREZ, Laureano (coord.). Pobreza, marginación y asistencia en la Península Ibérica (siglos XVI-XIX). León: Universidad de León, 2009, pp. 65-96.

82. Sobre las obras pías en Palencia puede verse MARcos MarTín, Alberto. Economía, sociedad..., op. cit., pp. 481-491.

83. El Evangelio de san Mateo $(25,34-40)$ lo expresa claramente: "Porque tuve hambre, y me disteis de comer; tuve sed, y me disteis de beber; peregriné, y me acogisteis; estaba desnudo y me vestisteis; enfermo, y me visitasteis; preso, y vinisteis a verme». 
su fundador ${ }^{84}$. Unas se dedicaban a repartir alimentos a los mendigos o a vestir a los pobres, mientras que otras se ocupaban en dotar doncellas huérfanas o en mantener a estudiantes.

Pero el objeto de estudio de este trabajo no se centra en el análisis de la caridad privada ejercida por benefactores, cofradías y hospitales, sino en la que pusieron en práctica los poderes públicos en momentos muy concretos, las jornadas de fiesta. Así, el ejercicio de la labor benéfica llevado a cabo en el desarrollo de las celebraciones públicas palentinas en el Antiguo Régimen correspondió en gran medida al Ayuntamiento, por lo que podemos hablar de una caridad pública, costeada mayoritariamente a expensas del erario municipal. A veces, la iniciativa se producía a instancias de la monarquía, pero otras tantas, partía del propio Concejo a imitación de lo practicado en otras ciudades o en la corte. También, en menor medida, se dieron casos puntuales de gestos de solidaridad entre los miembros de un mismo gremio para apoyar a los más desfavorecidos o iniciativas espontáneas de generosidad que hacían algunos regidores municipales a título personal en tiempos de crisis (donación de cargas trigo o limosnas).

De esta forma, según la finalidad, se pueden distinguir dos grupos de beneficiarios de la actividad caritativa. El primero, y más grande, está formado por aquellos colectivos que obtuvieron ayuda y asistencia con fines benéfico-sociales, bien fuese en forma de dinero (limosna o dotes), bien a través de alimentos o vestido. En esta categoría encontramos a las doncellas y niños huérfanos, los mendigos y enfermos, y los presos, pero también los labradores y artesanos empobrecidos, y los oficios gremiales que sufrieron en sus propias carnes la miseria y la pobreza coyuntural ${ }^{85}$.

En segundo lugar, fuera del alcance benéfico-asistencial, encontramos otro colectivo muy distinto, que se vio favorecido por la vertiente cultural y educativa de la fiesta, poco practicada y, por lo tanto, menos conocida. Se trata de los niños de escuela que a través de los concursos de exámenes organizados en el transcurso de las celebraciones (a inicios del siglo XIX) consiguieron diversos premios, algunos muy útiles en su formación académica, como libros o material escolar, además de medallas de metal precioso en recompensa al mérito.

\subsection{Fines benéfico-sociales}

En Palencia podemos advertir que la asistencia propia de los momentos festivos comienza a aplicarse de forma sistemática a partir de 1771, favorecida por los

84. Marcos Martín, Alberto. Economía, sociedad..., op. cit., p. 483.

85. En este sentido, debemos señalar la diferencia conceptual que ya estableció Alberto Marcos en 1985 entre "pobres estructurales» y "pobres coyunturales». Los primeros son los pobres permanentes, fruto de las estructuras sociales y económicas del Antiguo Régimen, mientras que los segundos son los pobres circunstanciales, "producto de las crisis cíclicas que descubren con dramática periodicidad la fragilidad y los desequilibrios del sistema». MARCos MarTín, Alberto. Economía, sociedad..., op. cit., p. 389. 
nuevos tiempos y el cambio de mentalidad impulsado por el espíritu de la Ilustración. Así, el nacimiento del primer nieto de Carlos III en aquella fecha sentaba un precedente no solo en las celebraciones de los natalicios de los infantes de la monarquía, sino también en la concepción de una nueva forma de entender la sociedad $^{86}$. El monarca ilustrado, consciente de la situación de miseria que atravesaba la población más desfavorecida y en su deseo de «facilitar el bien y alibio de sus amados vasallos», ordenó a los municipios no dilapidar el dinero en festejos porque solo servía para «distraer de su trabajo a las gentes y demás perjuicio que beneficio a la causa pública ${ }^{87}$.

La carta recibida por la ciudad en 1771, enviada por el conde de Aranda, presidente del Consejo de Castilla, se interesaba por la costumbre que tenía Palencia en la celebración de los nacimientos de personas reales y el tipo de festejos hechos hasta el momento, así como «el tanto que hubiesen importado los gastos de los últimos exemplares en semejantes casos" ${ }^{88}$, y rogaba encarecidamente al municipio abstenerse de tomar medidas hasta recibir permiso del Consejo.

La aplicación de estas medidas sociales y benéficas no afectó por igual a los colectivos más vulnerables de la sociedad: doncellas y niños huérfanos, mendigos y enfermos, labradores y oficios gremiales empobrecidos, y presos.

\subsubsection{Las doncellas y niños buérfanos}

La propuesta regia de 1771, innovadora en cierto modo al estar impregnada de las ideas ilustradas, aunque con claras intenciones propagandísticas que buscaban reforzar la imagen de la Corona ${ }^{89}$, pretendía que "los caudales que havían de expenderse en festejos públicos y diputaciones a la corte ${ }^{90}$ fuesen invertidos en «dotar doncellas pobres y huérfanas para facilitar sus matrimonios con proporción a sus clases ${ }^{91}$. Con esta medida se frenaban los despilfarros municipales y se

86. MAZa Zorrilla, Elena. "Pobreza y hospitalidad pública en la ciudad de Valladolid a mediados del siglo XVIII». Investigaciones Históricas, 1982, 3, pp. 33-76.

87. AMP, Actas Municipales, 25/09/1771, f. 166v.

88. AMP, Actas Municipales, 01/09/1771, f. 154r. y v.

89. López López, Roberto Javier. Ceremonia y poder..., op. cit., pp. 124-125.

90. AMP, Actas Municipales, 26/03/1780, f. 37v.

91. AMP, Actas Municipales, 25/09/1771, f. 166v. Instrucción que ha de observarse para distribuir los caudales que se habian de emplear fiestas y regocijos públicos por el feliz nacimiento del infante, y por orden de S. M. se destinan para dotes de doncellas bonestas, pobres y huérfanas de padre. Madrid, 1771. GonZÁLEZ Cruz, David. «Nacidos para reinar: el ceremonial de la procreación en España y América durante el siglo XVIII». En GonzÁlez Cruz, David (ed.). Ritos y ceremonias en el mundo bispano durante la Edad Moderna. Huelva: Universidad de Huelva y Ayuntamiento de Almonte, 2002, p. 115. Sobre doncellas pueden verse los siguientes trabajos: Rial GARCíA, Serrana. «Casar doncellas pobres, paradigma de la caridad eclesiástica». Obradoiro de Historia Moderna, 1994, 3, pp. 71-85; SOBALER SECO, María Ángeles. "Obras pías y matrimonio en la Castilla rural de la época moderna. El caso de la tierra de Portillo en el siglo XVIII». En Pérez Álvarez, María José y MarTín García, Alfredo (coords.). 
favorecía la proliferación de familias. También en 1780, con ocasión del natalicio del infante Carlos Domingo, se volvió a repetir esta dinámica. La cédula ponderaba "los admirables efectos que han producido en el reyno las dotes que se distribuyeron ${ }^{92}$ con igual motivo del nacimiento del infante Carlos Clemente nueve años atrás y se pedía a los ayuntamientos hacer balance del estado de sus arcas y elaborar un informe del gasto que fuese sometido a la aprobación del Consejo. Sin embargo, parece que estas decisiones no eran incompatibles con la conmemoración de ciertos regocijos en las capitales de provincia para "celebrar un suceso tan feliz y de tan grandes e importantes consequencias para toda la monarquía ${ }^{93}$, pues la costumbre de organizar saraos seguía muy arraigada entre la población.

Ya en los albores del siglo XIX, durante la dominación francesa, las festividades dedicadas a la onomástica de José I cada 19 de marzo tuvieron en común varios elementos: la iluminación, el vuelo de campanas y los espectáculos taurinos, aunque la función de 1811 presentaba ciertas novedades que rompían con la tradición de ediciones anteriores. El habitual baile y los gastos derivados de tan costosas funciones fueron sustituidos por la dotación de doncellas huérfanas, honestas y pobres para concertar sus matrimonios en un intento de atraer al pueblo y blanquear la desprestigiada figura de una monarquía ilegítima, encabezada por un gobernante extranjero e impopular. Esta medida fue concebida por el gobierno bonapartista como "una de las obras más útiles al Estado»"4, ya que el dinero destinado al regocijo de unos pocos podría ser invertido en beneficio público. Además, las autoridades se preocuparon en reforzar el sentido de la austeridad y la caridad, añadiendo un elemento religioso propio del tiempo litúrgico de la Cuaresma ${ }^{95}$.

El procedimiento para elegir a las tres mozas de entre las más de cien candidatas se efectuaba tomando como referencia principal las listas confeccionadas por los curas de las cinco parroquias. Todas debían cumplir varios requisitos: ser naturales de la ciudad (para las forasteras se requería acreditar dos años de residencia), solteras, tener entre 15 y 30 años de edad, vivir en situación de pobreza y orfandad y gozar de buena vida y costumbres, con las cualidades de honestidad y recato. El sorteo se llevaba a cabo mediante el sistema de cédulas de papel con nombre y apellido y filiación parroquial. Las agraciadas recibían una ayuda económica de cien ducados para contraer matrimonio ${ }^{96}$. Estas «dotes sociales», como

Campo y campesinos en la España Moderna. Culturas políticas en el mundo hispano. León: Fundación Española de Historia Moderna, 2012, vol. 2, pp. 1299-1313.

92. AMP, Actas Municipales, 26/03/1780, ff. 37v.-38r.

93. AMP, Actas Municipales, 26/03/1780, f. 38r.

94. AMP, Actas Municipales, 09/03/1811, ff. 98v.-99r.

95. CruZ Macho, Francisco Javier de la. "La Iglesia palentina durante la guerra de la Independencia». El Diario Palentino, 11/04/2010.

96. En 1811 resultaron elegidas Anastasia Fernández, de la parroquia de la catedral, de 15 años; Lorenza Sáez, perteneciente a la de san Miguel, de 19 años, y Gertrudis Camizo, feligresa de san Lázaro, 
actualmente las denomina la historiografía, tenían un valor significativo, asegurando, por tanto, un casamiento conveniente.

El programa festivo de la aclamación real de Isabel II (1833) fue el único de todas las proclamaciones celebradas en el Antiguo Régimen que contó con diversas medidas sociales y asistenciales, pues nunca antes se habían adoptado en una función de estas características en Palencia. Por decisión municipal se acordó dotar a cuatro doncellas huérfanas con 500 reales y proporcionar ropa a doce muchachos necesitados, pues vestir al pobre harapiento constituía también una obra de caridad $^{97}$. El coste corrió a cargo del Ayuntamiento, cuyo desembolso supuso alrededor del $10 \%$ de todo el presupuesto festivo ${ }^{98}$. El sorteo para el reparto de los dos mil reales entre las doncellas se hizo unos días después de la proclamación de la reina ${ }^{99}$. Los niños, que también tenían que ser huérfanos y contar entre diez y doce años, recibieron de forma gratuita un atuendo consistente en pantalón y chaqueta de paño pardo, camisa de lienzo, sombrero y zapatos ${ }^{100}$.

\subsubsection{Mendigos y enfermos}

Conocidos fueron los esfuerzos llevados a cabo por la monarquía a la hora de limitar el dispendio realizado por las ciudades en las celebraciones reales. En el último tercio del siglo XVIII, como ya se ha mencionado, Carlos III adoptó algunas medidas que frenaban los despilfarros municipales, favoreciendo la inversión en aspectos benéficos ${ }^{101}$. Sin embargo, a veces la iniciativa partía de los concejos. Conscientes de la situación de pobreza de gran parte de la población, algunos regidores y diputados del común alzaron su voz con el fin de aportar mejoras. Ciertos gestos de los munícipes a título individual coadyuvaron a la puesta en práctica de estos planteamientos. Así, en la proclamación de Carlos IV en 1789, el regidor encargado de levantar el estandarte, Cristóbal Ramírez, cedió de forma íntegra los 750 reales que le correspondían en concepto de ayuda de costa, dando 400 a los

de 21 años. AMP, Actas Municipales, 18/03/1811, ff. 116v.-118v. En 1813, se eleva a cinco el número de dotes, rebajando la cuantía a 50 ducados.

97. De nuevo, siguiendo a san Mateo (25, 36): «estaba desnudo y me vestisteis».

98. Se debe tener en cuenta que solo la dotación de doncellas (2.000 reales) supuso el $8 \%$, al que habría que añadir la partida correspondiente de la vestimenta de los 12 niños. La proclamación de Isabel II supuso un coste global de 27.740 reales al erario público.

99. AMP, Actas Municipales, 30/11/1833, s. f. Las agraciadas fueron Eulogia de Juana, Eusebia Gómez, María Díez y Saturnina Ibáñez Sandoval, elegidas de entre 58 candidatas.

100. AMP, Actas Municipales, 12/11/1833, s. f. Sobre vestido y pobreza puede verse el trabajo de García Fernández, Máximo. "Vestidos pobres: consumos estancados. Valladolid en el siglo XVIII". Estudios Humanísticos. Historia, 2016, 15, pp. 69-95. Sobre infancia y asistencia, Pérez Álvarez, María José y MARTín GARCíA, Alfredo. Marginación, infancia y asistencia en la provincia de León a finales del Antiguo Régimen. León: Universidad de León, 2008.

101. El reformismo social carolino puede verse en DomínguEz OrTiz, Antonio. Sociedad y Estado en el siglo XVIII español. Barcelona: Ariel, 1984, pp. 321-344. 
pobres del hospicio "para que tengan qué comer en los días de las funciones» ${ }^{102}$. Como gobernantes inclinados al servicio público, la renuncia a esa cantidad de dinero se hacía por "amor al bien común»" ${ }^{103}$, en beneficio de la república, aunque estos actos de caridad hacia los más desfavorecidos irremisiblemente contribuían a remarcar la posición social de los participantes dentro de la ciudad ${ }^{104}$.

Otras labores de caridad puestas en práctica durante la etapa napoleónica en estas celebraciones a partir de 1809 giraron en torno al reparto de alimentos o limosnas, ya fuera con fines propagandísticos o para desactivar fenómenos de posible sedición ${ }^{105}$. De esta forma, las autoridades galas instaban a los párrocos a elaborar «una lista de los pobres miserables de sus respectibas parroquias que por su situación sean acrehedores a recibir una ración de pan, vino y vianda» ${ }^{106}$. Habitualmente el coste de los alimentos procedía del fondo de las provisiones militares. También era costumbre que esta entrega se hiciera en forma de dinero, como ocurrió en 1813 a través del reparto de doscientas limosnas de seis reales.

Como ya se ha visto, el aniversario de la Constitución de 1812 fue solemnizado en Palencia en diversas ocasiones, de forma particular, durante el Trienio Liberal. La celebración solía constar de varias partes: la función religiosa con tedeum en la catedral, el acto militar en la plaza de la Constitución, el banquete, la corrida de novillos, el espectáculo de fuegos artificiales y el baile. Sin embargo, la función de 1821 contó además con un gesto hacia los más desfavorecidos de la ciudad. Pero la generosidad esta vez brilló por su ausencia, ya que los elementos sociales incluidos en este reparto benéfico, las personas impedidas para trabajar (lisiados y tullidos) y los «miserables pordioseros» ${ }^{107}$, tan solo recibieron la comida sobrante del festín, es decir, las migajas.

La presencia de los reyes en la ciudad también conllevaba ciertas prácticas caritativas. Así se observa en la visita a Palencia en 1828 de Fernando VII y María Josefa Amalia y el interés mostrado a la hora de visitar el hospital de San Bernabé y San Antolín para conocer "uno por uno a todos los enfermos de ambos sexos y a los niños espósitos» ${ }^{108}$ y admirar «la buena asistencia y caritativas atenciones que se prodigan a los muchos enfermos que entran en él» ${ }^{109}$. En ejercicio de un

102. AMP, Actas Municipales, 15/04/1789, f. 103r. Los otros 350 reales fueron destinados a los presos pobres.

103. AMP, Actas Municipales, 06/02/1789, f. 47v.

104. MARTíneZ RAmos, Antonio. Fiestas reales en la Granada del siglo XVIII: celebraciones urbanas en torno a la Monarquí. Tesis doctoral. Granada: Universidad de Granada, 2013, p. 197.

105. OMEs, Marco Emanuele. "Celebraciones napoleónicas y josefinas en la España de la Guerra de la Independencia». En SERrano, Rafael et al. (eds.). Dimensiones religiosas de la Europa del Sur (1800-1875). Valladolid: Universidad de Valladolid, 2018, p. 30.

106. AMP, Actas Municipales, 11/03/1811, f. 101r.

107. AMP, Actas Municipales, 12/03/1821, ff. 109v.-112r.

108. GÓmeZ DE Robledo, Juan Antonio. Venida de los SS. Reyes..., op. cit., f. 10r.

109. Itinerario y diario del viage ejecutado por el rey nuestro señor, desde el Real Monasterio de San Lorenzo para la plaza de Tarragona, en 22 de septiembre de 1827, hasta el 11 de agosto de 1828, 
acto tan piadoso, los reyes dejaron en la ciudad, por vía de limosna, un total de 15.920 reales, repartidos de la siguiente manera: siete mil para los enfermos del hospital, otros siete mil para los pobres del hospicio y 640 a las comunidades de religiosas dominicas, bernardas y agustinas recoletas. No se debe olvidar que caridad, devoción y piedad formaban parte de los pilares fundamentales de todo buen gobernante cristiano ${ }^{110}$.

\subsubsection{Labradores, artesanos y otros oficios empobrecidos}

1783 dejó en muchas ciudades del país un memorable festejo doble que aunaba dos hechos trascendentales para la monarquía española: el nacimiento de los infantes gemelos, hijos del príncipe de Asturias y nietos de Carlos III, y la firma del tratado de paz con Gran Bretaña ${ }^{111}$. El natalicio de Carlos y Felipe resultó ser un hecho providencial para la dinastía Borbón, ya que la muerte de Carlos Clemente (1774) y Carlos Domingo (junio de 1783) situaba a los gemelos en el primer puesto de la línea sucesoria ${ }^{112}$.

Lo más llamativo de esta celebración fue la práctica que, a instancias de la Corona, llevó a cabo un gremio palentino, el de La Puebla, el más importante del ramo textil, especializado en la fabricación de mantas, cobertores y acolchados, que tenía en la ciudad su barrio particular, denominado La Puebla, donde estaban todas sus fábricas y obradores ${ }^{113}$. La medida, un precedente en las celebraciones de este ámbito, consistía en distribuir 300 ducados (3.320 reales) de los fondos propios en ayuda de los más pobres del gremio con arreglo al capítulo octavo

que regresó a la villa y Corte de Madrid, con su augusta esposa la reyna nuestra señora. AGP, Reinados, Fernando VII - Papeles Reservados, t. 86, f. $215 \mathrm{v}$.

110. Quijada Álamo, Diego. "La exaltación de las virtudes en la oración fúnebre de la reina María Josefa Amalia de Sajonia (1829)». En Torremocha Hernández, Margarita (ed.). Mujeres, sociedad y conflicto (siglos XVII-XIX). Valladolid: Castilla Ediciones, 2019, pp. 71-74.

111. Sobre esta celebración pueden verse diversos trabajos: SuBIRANA REBULL, Rosa María. "Arte, poder y sociedad en la fiesta barroca: celebración y máscara real en Barcelona con motivo del tratado de Versalles y el nacimiento de los infantes Carlos y Felipe, hijos del futuro Carlos IV (1783)». En El arte en las cortes europeas del siglo XVIII. Madrid: Comunidad de Madrid, Consejería de Cultura, 1989, pp. 725-731; Lolo HERRANZ, Begoña. «Fiestas para la celebración del natalicio de los gemelos de Carlos IV (1784). "Los Menestrales» de Cándido María Trigueros con música de Blas de Laserna». Revista de Musicología, 2005, 28, 2, pp. 1265-1280; DíAZ JiménEZ, Isidro. "Fiestas por el nacimiento de los infantes gemelos Carlos y Felipe. Sevilla, 1783-1784». En Actas XIV Jornadas de Historia y Patrimonio de la provincia de Sevilla. Ferias, fiestas y romerías en Sevilla: el ciclo festivo local. Sevilla: Asociación Provincial Sevillana de Cronistas e Investigadores Locales, 2018, pp. 105-127.

112. Embarazo real sobre el nacimiento de los infantes gemelos, 1783. AHN, Estado, leg. 2475, exp. 11.

113. Sobre el sector textil manufacturero en Palencia en el siglo XVIII, véase GARCía ColmENARES, Pablo. Evolución y crisis de la industria textil castellana. Palencia (1750-1990). "De la actividad artesanal a la industria textil». Madrid: Mediterráneo, 1992. También, Marcos MarTín, Alberto. Economía, sociedad..., op. cit., pp. 281-292. 
de la cédula de Carlos III $^{114}$, siguiendo el espíritu ilustrado y las iniciativas regias aplicadas en pro de la beneficencia. La propuesta fue aprobada por el corregidor, que nombró a un regidor para que con la intervención de los veedores gremiales se hiciera el reparto adecuado entre aquellos individuos más desfavorecidos ${ }^{115}$. La alegría de la fiesta llegaba a grupos sociales que antes eran meros espectadores.

Otra actividad precursora que nunca antes se había observado guarda también estrecha relación con el imperativo de la cédula en lo referente a la dotación de huérfanas y ayuda a labradores necesitados. Lo extraordinario del caso no es, como se ha visto ya, la inversión de dinero público en fines asistenciales, sino las "demostraciones de piedad» realizadas a iniciativa propia por los regidores municipales, que dieron ejemplo al ofrecer 52 fanegas de trigo al pueblo en forma de limosna, especialmente "para el socorro de labradores de esta ciudad [por ser] una de las piadosas intenciones de S.M.»" ${ }^{116}$. El procurador síndico general, Diego de Sierra, ofreció veinte fanegas; Cristóbal García Ramírez, diez; Nicolás Gil de Palacio, doce; Antonio Díez Paniagua, seis, y Rafael Blanco de Salcedo (procurador personero del público), cuatro.

Numerosos fueron los festejos que la ciudad organizó con ocasión de la proclamación de Carlos IV en 1789. Sin embargo, algunas voces críticas en el seno del Concejo apostaban por la suspensión total de los regocijos diseñados por los gremios, pues lo que

parecía un inconveniente es en realidad un insigne beneficio del común, [porque] el más crecido número de la gente de oficios es pobre y está atenida a su jornal o trabaxo diario para mantenerse y a su familia, que resulta tan miserable, se seguirán del mucho tiempo que han de quitar a su trabajo en los días de las funciones, en los que han de proceder para los ensayos, en los escotes y contribución semanal para los gastos, meriendas y refrescos ${ }^{117}$.

Otra de las propuestas, algo menos radical, abogaba por eliminar solo algunas actividades de los gremios, "pues estos, para acabarse de arruinar piensan en tomar un censo para hacer más lucida su mogiganga» ${ }^{118}$. Los regidores emplearon un argumento basado en la gran inversión (más de mil ducados) que hizo el Ayuntamiento para auxiliar a los oficios afectados por la epidemia de tercianas de 1786

114. Real cédula de S.M. y señores del Consejo, en la qual se expresan las demostraciones de piedad y regocijos públicos que deven hacerse en todo el Reino con motivo de los prósperos sucesos que ha experimentado esta Monarquía en el feliz parto de la princesa nuestra Señora, nacimiento de los dos infantes Carlos y Felipe y el ajuste definitivo de paz con la nación británica. Palencia: en la Oficina de don Francisco Javier Riesgo, 1783. AMP, Gobierno, Disposiciones recibidas, Reales Cédulas, caja 60, Real Cédula 1783, 22 de octubre, n. ${ }^{\circ} 123$ (impresa).

115. La relación de la distribución de los 3.320 reales hecha por el gremio de La Puebla entre los pobres individuos del mismo gremio se vio en AMP, Actas Municipales, 06/02/1784, f. 85r.

116. AMP, Actas Municipales, 21/11/1783, f. 335v.

117. AMP, Actas Municipales, 06/02/1789, ff. 46v.-47r.

118. AMP, Actas Municipales, 06/02/1789, f. 46v. 
y 1788, evitando, siempre que fuese posible, "los excesos y la destemplanza»19. Las actas municipales no revelan la resolución de estas iniciativas, pero resulta evidente que no llegaron a buen puerto, bien por la oposición del pleno municipal, bien por la resistencia a los cambios en la mentalidad colectiva, pues finalmente los gremios realizaron sus comparsas y desfiles para festejar la llegada al trono de Carlos IV, tal y como marcaba la costumbre.

Por último, las festividades por el aniversario de la Constitución en 1821 también tuvieron muy presentes a los jornaleros y artesanos más pobres de la ciudad -mucho mejor valorados que los mendigos y enfermos-, que obtuvieron una limosna en metálico de cuatro reales, medio pan y media azumbre de vino.

\subsubsection{Presos de la cárcel}

El programa festivo de algunas celebraciones también contaba con ciertas medidas de alivio destinadas a los "infelices encarcelados" ${ }^{120}$, como era el reparto de una ración de comida o la distribución de ropa ${ }^{121}$. Así se observa en el aniversario de la Constitución de Cádiz (1821), pero también en el ascenso al trono de Carlos IV (1789) e Isabel II (1833). La diferencia entre una proclamación y otra radica en el origen de la iniciativa, pues mientras que la primera fue únicamente un gesto espontáneo de generosidad del alférez mayor al donar 350 reales a los "pobres de la cárcel»" para que estuvieran alimentados los días festivos, la segunda formaba parte de la decisión adoptada por el pleno municipal. En cambio, en las fiestas del dominio napoleónico (1809-1813) destaca principalmente el reparto de camisas y calzado, especialmente entre los prisioneros del ejército español ${ }^{123}$,

119. AMP, Actas Municipales, 06/02/1789, f. 47r. GARCía COLMENAREs, Pablo. Evolución y crisis..., op. cit., p. 65. Sobre la crisis de la industria textil y el sistema gremial en Palencia a finales del XVIII e inicios del XIX, pp. 135 y ss.

120. AMP, Actas Municipales, 12/03/1821, ff. 109v.-112r.

121. Semejantes medidas fueron aplicadas en Sevilla, incluyendo la liberación de presos: CABEZAS GARCÍA, Álvaro. «Vanidad imperial y estética del artificio: fiestas napoleónicas en la Sevilla ocupada». Laboratorio de Arte, 2012, 24, pp. 514-515.

122. Sobre presos pobres puede verse el trabajo de TORREMOCHA HERnÁNDEZ, Margarita. "Presos pobres, pobres presos: asistencia en la cárcel de la ciudad de Valladolid (siglo XVII)». En SOBALER SeCo, María Ángeles y García Fernández, Máximo (coords.). Estudios en bomenaje al profesor Teófanes Egido. Valladolid: Junta de Castilla y León, 2004, vol. 1, pp. 403-422.

123. A este respecto, el cumpleaños de Fernando VII en 1812 dejó tras de sí una novedad cuando la corporación municipal decidió cambiar el rumbo de los festejos públicos tomando la decisión de invertir el importe asignado en cuestiones más beneficiosas para una nación que se hallaba en guerra, como la de "surtir de zapatos y otros artículos de necesidad a nuestros defensores». Esta medida sentaba un precedente en tanto en cuanto modificaba las intenciones regias, que hasta entonces habían tenido un cariz social y benéfico-asistencial, aplicado en los sectores más desfavorecidos (doncellas huérfanas y pobres, labradores humildes, etc.), por otros fines más propios de los tiempos bélicos, al tratar de mejorar el pertrecho de los soldados, dado que el calzado resultaba indispensable para cualquier ejército. AMP, Actas Municipales, 12/10/1812, f. 639v. 
que aparecen diferenciados de los presos comunes. La comida y vestimenta de la fiesta de la onomástica de José Bonaparte en 1813 corrió a cargo de los regidores Miguel de Soto (llegará a ser alcalde de Palencia en 1838) y Vicente García Llamas.

Otra medida mucho más ventajosa, pero también menos frecuente, era la concesión real de indultos a "los presos sin parte» ${ }^{124}$ con motivo de la jura de los herederos ${ }^{125}$, las proclamaciones y los natalicios de los príncipes ${ }^{126}$. El advenimiento de Fernando VI al trono trajo consigo un indulto, publicado el 31 de octubre de 1746, en favor de los presos que hubiera en las cárceles de Palencia y su provincia. Se trataba de un perdón general, pero "con la circunstancia de que no haian de ser compreendidos los reos a quienes la gravedad de sus delitos haga indignos de esta gracia» ${ }^{127}$. Quedaban excluidos, por tanto, ladrones, gitanos, mujeres de la galera, crímenes de lesse mayestatis, pecado nefando, reniegos, acusados de blasfemia contra Dios, muerte alevosa, contrabandistas de géneros prohibidos, falsificadores de moneda y, en general, todas aquellas personas que hubiesen ofrecido resistencia armada a la justicia del rey. En este sentido, el uso de la clemencia y piedad marcaba el inicio de un reinado que debía empezar con acierto y buena voluntad por parte de un monarca que era el primer juez del reino, y la institución monárquica, por lo mismo, la entidad promotora de Justicia ${ }^{128}$.

También en 1823, con motivo del acceso al trono por tercera vez de Fernando VII, finalizado el Trienio Liberal, se adoptaron algunas medidas benevolentes y, en cierto modo, paternalistas, como la liberación de «los presos que se hallan en la cárcel por opinión » ${ }^{129}$, a imitación de la libertad recobrada por el monarca ${ }^{130}$. El indulto no incluía a aquellos reos que tuvieran causa formada, aunque, en

124. Presos que tenían causas iniciadas de oficio y no había denuncia de parte.

125. HuRTAdo DE Mendoza, Antonio. Ceremonial que se observa en España para juramento de príncipe hereditario, o convocación de las Cortes de Castilla, según se ha executado desde el juramento del príncipe nuestro señor don Baltasar Carlos, primero de este nombre. Madrid: Imprenta de González, 1789, p. 97.

126. Torremocha Hernández, Margarita. Cárcel de mujeres en el Antiguo Régimen. Teoría y realidad penitenciaria de las galeras. Madrid: Dykinson, 2019, pp. 270-271. Sobre indultos a presos con motivo de los partos de las reinas véase González Cruz, David. "Nacidos para reinar...", op. cit., pp. 115-116.

127. AMP, Actas Municipales, 11/11/1746, f. 225v.

128. TORREMOCHA HERnÁNDEZ, Margarita. "Espiritualidad y moralidad en el patrón de un juez perfecto en la Edad Moderna». En Pérez Álvarez, María José y Martín García, Alfredo (coords.). Religión, política y patrimonio en la Península Ibérica (siglos XIII-XXI). Madrid: Síntesis, 2018, p. 169; CONTRERAS CONTRERAS, Jaime. «Sociedad confesional: Derecho público y costumbre». En ARANDA PÉREZ, Francisco José (coord.). Poderes intermedios, poderes interpuestos. Sociedad y oligarquías en la España Moderna. Cuenca: Universidad de Castilla-La Mancha, 1999, p. 65; HerAs SANTOS, José Luis de las. "La organización de la justicia real ordinaria en la Corona de Castilla durante la Edad Moderna». Estudis: Revista de Historia Moderna, 1996, 22, pp. 105-139.

129. AMP, Actas Municipales, 07/10/1823.

130. Contreras Contreras, Jaime. "Sociedad confesional...", op. cit., p. 70. Torremocha HerNÁNDEZ, Margarita. Cárcel de mujeres..., op. cit., p. 271. 
compensación, podrían recibir una comida. Resulta interesante fijar la atención en el concepto de libertad de opinión, pues se trata de una cuestión relevante que ya indica la existencia de una sociedad ciertamente politizada, donde las ideas podían suponer una amenaza para el sistema absolutista, que entonaba su canto de cisne ante la inminente irrupción del liberalismo.

\subsection{La vertiente cultural de la fiesta: los concursos de niños de escuela}

La educación es uno de los pilares que vertebra la sociedad del siglo de las Luces. En Palencia, esta se impartía en varios centros. Unos estaban en manos de los poderes eclesiásticos, como el Seminario ${ }^{131}$, el Estudio del convento de los dominicos, y la Escuela de gramática, que dependía del Cabildo. Por otra parte, existían desde 1767 dos escuelas de enseñanza pública de primeras letras, financiadas por el Concejo, donde se enseñaba a los niños a leer, escribir y contar ${ }^{132}$. Las niñas, en cambio, tuvieron que esperar hasta 1817, a pesar de la iniciativa promovida por un diputado del común en 1775 para crear una escuela gratuita que estuviese atendida por dos maestras, "por juzgar el ayuntamiento ser mui útil y en veneficio de la causa pública» ${ }^{133}$.

Además de los colectivos desfavorecidos ya señalados, los niños ${ }^{134}$ fueron también un foco especial de atención en determinados eventos de la Palencia festiva de inicios del siglo XIX. El programa de festejos de la última edición de la onomástica de José I, celebrada en 1813, además de contar con las habituales diversiones y medidas sociales, aportó una interesante novedad cultural: la realización de un concurso de exámenes destinado a los escolares. Esta disposición resulta muy llamativa porque constituye el primer caso documentado en la ciudad a lo largo del Antiguo Régimen.

131. Torremocha Hernández, Margarita. «La formación del clero. El plan de estudios del Seminario Conciliar de San José de Palencia de 1779». En Actas del II Congreso de Historia de Palencia. Palencia: Diputación Provincial, 1990, vol. III, pp. 395-410.

132. Lo cierto es que desde 1695 estas escuelas ya funcionaban, bajo el patronato del Ayuntamiento para el pago de algunos gastos, pero vinculadas a los jesuitas, en un edificio contiguo al colegio de la Compañía de Jesús. Tras su expulsión en 1767, el municipio se hizo cargo plenamente de estos centros. Díaz Palenzuela, Luis Ángel. "Sanidad y educación en la ciudad de Palencia en el siglo XVIII: la salud y la medicina, las escuelas de primeras letras y otros centros de enseñanza». Publicaciones de la Institución Tello Téllez de Meneses, 2002, 73, pp. 179-180. Sobre la enseñanza y la cultura en el último tercio del siglo XVIII véase Domínguez OrTIZ, Antonio. Carlos III y la España de la Ilustración. Madrid: Alianza, 1989, pp. 161 y ss.

133. AMP, Actas Municipales, 26/10/1775, f. 394r.

134. Sobre la infancia en la Edad Moderna resulta indispensable la obra de ARIÈs, Philippe. El niño y la vida familiar en el Antiguo Régimen. Madrid: Taurus, 1987. Una breve síntesis general también en Herranz PInAcho, María. Tutela y curaduría en la familia de Hernando Daza, mercader de Medina del Campo. Valladolid: Universidad de Valladolid, 2018, pp. 22-33. 
El examen, que tenía como meta favorecer el saber, las artes y las letras, fue celebrado en la sala principal del consistorio en presencia de algunos regidores y los comisarios de escuelas. Aunque existía una acusada diferencia de edad, el ejercicio destinado a los alumnos de gramática entrañaba mayor complejidad, ya que constaba de una «lectura de autores latinos y españoles, traducción y análisis de las partes de la oración " ${ }^{135}$. Los veinticinco chicos más aventajados obtuvieron un premio consistente en una medalla de plata. La anécdota estuvo protagonizada por dos escolares, únicos integrantes de la misma clase, que fueron merecedores de idéntico galardón. Como solo quedaba una medalla, las autoridades supieron resolver con apremio la situación, acordando otorgar a uno de ellos un libro de «un autor clásico que le pudiese combenir, latino o castellano, de edición y enquadernación escogida, en cuya pasta se expresase con letras doradas que era dado por la Ciudad en premio de aplicación»" ${ }^{136}$. El suceso, que apenas reviste trascendencia, ponía de relieve el coste material y el valor económico de un libro al ser equiparado a una medalla bañada en metal precioso.

Idéntica actividad volvió a repetirse tres años después en obsequio de Fernando VII con motivo de su santo, queriendo mostrar a la sociedad «un testimonio de los adelantamientos y enseñanza que se da a la juventud en las escuelas de primeras letras» ${ }^{137}$, mediante la convocatoria de exámenes públicos el día festivo más inmediato al de san Fernando. Estos tuvieron lugar el 26 de mayo en la sala consistorial de la Plaza Mayor. El premio consistía en seis medallas de plata, que después aumentaron en doce, grabadas con las armas de la ciudad, el busto del rey y una inscripción alusiva al mérito y la virtud. Estaban destinadas a los alumnos más adelantados, aunque el Ayuntamiento se reservaba la capacidad de distribuir también «algunos libros o algún otro utensilio que pueda serles apreciable para su aprovechamiento ${ }^{138}$.

Entre los mandatarios civiles, militares y religiosos que asistieron al acto público se encontraban el intendente - era la primera autoridad civil de la provincia, cuya posición se veía reforzada al acumular el corregimiento de la ciudad-, el obispo, el coronel del regimiento de Dragones de Pavía, varios regidores y otros tantos prebendados de la catedral, curas parroquiales y priores de las comunidades religiosas, «siendo tan numeroso el concurso de las demás clases del pueblo que muchas personas se privaron del placer de un acto tan tierno por falta de sitio donde colocarse» ${ }^{139}$.

El examen se limitó a la clase de los jóvenes de la escuela de escribir, que es distinta de la de leer, cuyo inicio estuvo marcado por un discurso pronunciado

135. AMP, Actas Municipales, 18/03/1813, f. 161r.

136. AMP, Actas Municipales, 18/03/1813, f. 161v.

137. AMP, Actas Municipales, 18/04/1816, f. 166r.

138. AMP, Actas Municipales, 18/04/1816, f. 166r.

139. AMP, Actas Municipales, 06/06/1816, ff. 255v.-256r. 
por Romualdo de la Tejera y Bruno Martínez, niños de diez años. Después se presentaron 36 discípulos y mutuamente se preguntaron y respondieron sobre los principios de la religión y la historia sagrada, "que son los fundamentos sólidos para formar buenos ciudadanos». Seguidamente, se procedió al examen según las diversas materias: ortología, caligrafía, ortografía, gramática castellana, aritmética, geografía e historia de España y algunas nociones relativas a las Fábulas de Samaniego. Entre los asistentes "causó una dulce sorpresa y un regocijo extraordinario el hallar cimentadas tantas luces y conocimientos, admirándose de la viveza y exactitud con que se portaron los jóvenes ${ }^{140}$. Se concedieron las medallas a los doce mejores, dejando para los demás alumnos «otras señales de aprecio, [como] libros preciosos, cortaplumas y otros agasajos apetecidos de la jubentud ${ }^{141}$. Este concurso despertó también la generosidad del obispo Francisco Javier Almonacid y el intendente, que aportaron donativos voluntarios «en socorro de algunos jóvenes, los más pobres", pues no debemos olvidar que a la escuela también asistían muchos niños humildes ${ }^{142}$.

El coste total de esta conmemoración fue de 370 reales, cantidad que de forma íntegra correspondió al importe de los premios de los niños. Esta innovación producida en la festividad del santo del rey marcaba un punto de inflexión que afectaba no solo al modelo celebrativo de las onomásticas, sino que cambiaba radicalmente el modo de concebir la fiesta, desplazando los festejos "poco edificantes» por un concurso que ponía a prueba las habilidades y conocimientos de los escolares de la ciudad. El escenario había cambiado por completo, así como la tipología de los festejos, incluidos los protagonistas, que pasaron a ser niños del pueblo, gente corriente. Aunque el fin de estas celebraciones públicas seguía siendo el mismo que tiempo atrás: ensalzar al monarca y a una dinastía.

\section{CONSIDERACIONES FINALES}

El estudio de la sociabilidad en la Palencia festiva a finales del Antiguo Régimen, abordado en este trabajo a través de la alimentación y la caridad ejercida por los poderes públicos en el transcurso de la fiesta, ha permitido ahondar en dos de las facetas menos conocidas de las celebraciones públicas.

El análisis de los productos consumidos por las autoridades urbanas en los ambigús y «refrescos» celebrados para conmemorar ciertas solemnidades permite

140. AMP, Actas Municipales, 06/06/1816, f. 256r.

141. AMP, Actas Municipales, 06/06/1816, f. 256r. Los niños agraciados fueron Bruno Martínez, Mariano Vian, Agapito Rodríguez, Faustino París, Mariano Juara, Telesforo Arévalo, Romualdo de la Tejera, Vicente de la Riva, Rafael Pérez, Dionisio Moratinos, Demetrio Astudillo y Francisco Polo.

142. De los 192 niños que acudían a las escuelas públicas en Palencia a finales del siglo XVIII, 47 eran pobres, es decir, el 25 \%. Dato ofrecido por Díaz Palenzuela, Luis Ángel. "Sanidad y educación...", op. cit., p. 180. 
establecer una diferenciación entre los alimentos propios de la sociabilidad privada y los que forman parte de los espacios públicos, dentro del marco festivo. Así, observamos que el cacao y el azúcar predominan en las mesas de las oligarquías, mientras que la limonada y el chocolate caliente constituyen las principales bebidas. Asimismo, la presencia de los reyes comportaba una abundantísima mesa de estado, provista de exquisitos manjares, donde no podía faltar la carne, en menor medida el pescado y el marisco, la legumbre, las verduras y hortalizas, la fruta, los dulces y confituras, y el vino, aunque esta bebida alcohólica fue muy apreciada por el estamento popular, como por los soberanos y dignatarios militares que visitaron la ciudad.

Pero la fiesta también alberga un aspecto novedoso, la dimensión asistencial, cuya iniciativa parte de la propia monarquía o incluso de las instituciones urbanas, que la ponen en práctica por orden del soberano. El precedente se halla en 1771, cuando Carlos III ordenó que una parte de la inversión del presupuesto festivo fuese destinada a fines benéficos, concretamente a la dotación de doncellas huérfanas. Así, algunos de los regocijos y espectáculos dirigidos al pueblo se vieron afectados en buena medida por la nueva corriente de pensamiento, auspiciada por la Ilustración, que transformó y derivó la concepción de la fiesta hacia una vertiente benéfico-asistencial a través de las limosnas, viandas, vestimentas y dotes repartidas por las autoridades civiles entre los colectivos más desfavorecidos (niños huérfanos, mendigos, enfermos, labradores y artesanos empobrecidos), incluidos los indultos para presos concedidos por los monarcas en celebraciones señaladas (acceso al trono, natalicio del príncipe heredero) con la intención de reforzar su imagen de soberano justo y piadoso.

Sin embargo, también existieron casos puntuales de gestos de solidaridad entre los miembros de un mismo gremio para apoyar a los más desfavorecidos o iniciativas espontáneas llevadas a cabo por algunos regidores municipales a título personal en tiempos de crisis mediante donativos consistentes en cargas de trigo o dinero.

A inicios del siglo XIX aflora también la vertiente utilitaria de la fiesta, propia de los tiempos de guerra (zapatos para el pertrecho de los soldados), pero sobre todo sociocultural y educativa, poco practicada y, por lo tanto, menos conocida. Esta surgió en Palencia como elemento innovador introducido por las autoridades napoleónicas (1813) en el programa festivo, que sustituía los festejos menos edificantes (toros y bailes) por aquellos que reforzaban el conocimiento y el saber científico, es decir, los concursos de exámenes de niños de escuela, que podían beneficiarse de diversos premios, como medallas, libros o material escolar (cortaplumas, por ejemplo). Esta medida, acorde con el espíritu ilustrado, tenía como finalidad última loar a los reyes (José I y Fernando VII) en calidad de benefactores de las letras y las artes. 


\section{Bibliografía}

Argüello Castrillo, A. Dictamen físico-médico-político sovre la epidemia de tercianas que por cerca de tres años reyna en el Pays de Campos, y particularmente en su capital, la ciudad de Palencia. Palencia: Imprenta de Álvarez, 1802.

CABEZAS García, Á. «Vanidad imperial y estética del artificio: fiestas napoleónicas en la Sevilla ocupada». Laboratorio de Arte, 2012, 24, pp. 511-525.

CONTRERAS Contreras, J. «Sociedad confesional: Derecho público y costumbre». En ARANDA PÉREZ, F. J. (coord.). Poderes intermedios, poderes interpuestos. Sociedad y oligarquías en la España Moderna. Cuenca: Universidad de Castilla-La Mancha, 1999, pp. 65-76.

CORADA AlOnso, A. Un beaterio en la Castilla del siglo XVIII: Vida y muerte en San Lázaro de Aguilar de Campoo. Palencia: Institución Tello Téllez de Meneses, 2015.

Cruz Macho, F. J. «La Iglesia palentina durante la guerra de la Independencia». El Diario Palentino, 11/04/2010.

Díaz Palenzuela, L. Á. «Sanidad y educación en la ciudad de Palencia en el siglo XVIII: la salud y la medicina, las escuelas de primeras letras y otros centros de enseñanza». Publicaciones de la Institución Tello Téllez de Meneses, 2002, 73, pp. 165-194.

Domínguez Ortiz, A. Sociedad y Estado en el siglo XVIII español. Barcelona: Ariel, 1984.

Domínguez Ortiz, A. Carlos III y la España de la Ilustración. Madrid: Alianza, 1989.

Drumond Braga, I. "O chocolate à mesa: sociabilidade, luxo e exotismo». Em Formas e espaços de sociabilidade. Contributos para uma História da Cultura em Portugal. Lisboa: Universidade Aberta, 2008, pp. 1-17.

EgIDO López, T. «La religiosidad colectiva de los vallisoletanos». En ENCISO ReCiO, L. M. et al. Valladolid en el siglo XVIII. Valladolid: Ateneo de Valladolid, 1984, pp. 157-260.

EgIDO LóPEZ, T. «Formas de religiosidad en la época moderna». En Valladolid. Historia de una ciudad (época moderna). Valladolid: Ayuntamiento de Valladolid, 1999, pp. 511-523.

El mejor día del año, fin de miserias, y principio de felicidades para la lealtad y para el amor de los palentinos: el solemne, festivo y venturoso día XV de octubre de MDCCLIX, en que la muy noble y muy leal ciudad de Palencia bizo la gloriosa aclamación de nuestro cathólico rey y señor Carlos Tercero (que Dios guarde). Valladolid: Imprenta de Alonso del Riego, [1759].

FlandRIN, J. L. «Historia de la alimentación: por una ampliación de las perspectivas». Manuscrits, 1987, 6, pp. 7-30.

García Colmenares, P. Evolución y crisis de la industria textil castellana. Palencia (17501990). "De la actividad artesanal a la industria textil». Madrid: Mediterráneo, 1992.

GARCía FERNÁNDEZ, M. «Vestidos pobres: consumos estancados. Valladolid en el siglo XVIII». Estudios Humanísticos. Historia, 2016, 15, pp. 69-95.

Gómez de Robledo, J. A. Venida de los SS. Reyes a Palencia y mansión en ella. Año de 1828. Relación individual y diario bistórico de las funciones hechas por la I. N. y L. ciudad de Palencia, para el recivimiento de SS.MM. con las demás ocurrencias, durante su detención y permanencia en ella. [Palencia], 1828.

GONZÁlez CRUZ, D. "Nacidos para reinar: el ceremonial de la procreación en España y América durante el siglo XVIII». En González Cruz, D. (ed.). Ritos y ceremonias en el mundo hispano durante la Edad Moderna. Huelva: Universidad de Huelva y Ayuntamiento de Almonte, 2002, pp. 91-119. 
Herranz Pinacho, M. Tutela y curaduría en la familia de Hernando Daza, mercader de Medina del Campo. Valladolid: Universidad de Valladolid, 2018.

HuRTADO DE MENDOZA, A. Ceremonial que se observa en España para juramento de príncipe hereditario, o convocación de las Cortes de Castilla, según se ha executado desde el juramento del príncipe nuestro señor don Baltasar Carlos, primero de este nombre. Madrid: Imprenta de González, 1789.

IsLA, J. F. Historia del famoso predicador fray Gerundio de Campazas, alias Zotes (Madrid, 1758). Barcelona: Planeta, 1991.

La lealtad en extremo y el festejo hasta su esfera: lo más que se pudo hacer y decir en la $M$. N. y antigua ciudad de Palencia en la solemne proclamación de nuestro católico rey y señor don Carlos IV (que Dios guarde). Palencia: Oficina de Francisco Xavier Riesgo y Gonzalorena, [1789].

LARRUga Boneta, E. Memorias políticas y económicas sobre los frutos, comercio, fábricas y minas de España, provincia de Palencia. Madrid: por don Antonio Espinosa, 1794.

López López, R. J. Ceremonia y poder en Galicia a finales del Antiguo Régimen. Santiago de Compostela: Universidad de Santiago, 1995.

LOZANO RuIZ, C. «Caridad y asociacionismo religioso conventual en Palencia durante la Edad Moderna (ss. XVI-XVIII)». En SERRANO MARTín, E. (coord.). De la tierra al cielo: líneas recientes de investigación en historia moderna. Zaragoza: Fundación Española de Historia Moderna, Institución Fernando el Católico, 2012, pp. 85-100.

Marcos Martín, A. Economía, sociedad y pobreza en Castilla: Palencia, 1500-1814. Palencia: Diputación Provincial, 1985.

marcos Martín, A. «Palencia en el siglo XVIII». En GonZÁlez GonZÁlez, J. (coord.). Historia de Palencia. Palencia: Diputación Provincial, 1995, pp. 83-122.

MARTíneZ RAMOs, A. Fiestas reales en la Granada del siglo XVIII: celebraciones urbanas en torno a la Monarquía. Tesis doctoral. Granada: Universidad de Granada, 2013.

MAZA Zorrilla, E. «Pobreza y hospitalidad pública en la ciudad de Valladolid a mediados del siglo XVIII». Investigaciones Históricas, 1982, 3, pp. 33-76.

Melgosa Oter, Ó. R. "Protagonistas en las exequias de los Austrias: los predicadores del sermón fúnebre». Obradoiro de Historia Moderna, 2007, 16, pp. 253-282.

MONTANARI, M. El hambre y la abundancia: historia y cultura de la alimentación en Europa. Barcelona: Crítica, 1993.

MONTANari, M. La comida como cultura. Gijón: Trea, 2006.

OMES, M. E. "Celebraciones napoleónicas y josefinas en la España de la Guerra de la Independencia». En SERRANo, R. et al. Dimensiones religiosas de la Europa del Sur (18001875). Valladolid: Universidad de Valladolid, 2018, pp. 13-32.

PARCERo Torre, C. y González lázAro, Á. «La relación de poderes en Palencia a mediados del siglo XVII». En Actas del III Congreso de Historia de Palencia. Palencia: Diputación Provincial, 1995, pp. 95-104.

PéreZ SAmper, M. a Á. "Luces, tertulias, cortejos y refrescos". Cuadernos de Estudios del Siglo XVIII, 2000-2001, 10-11, pp. 107-153.

PÉREZ SAMPER, M. ${ }^{a}$ Á. «Espacios y prácticas de sociabilidad en el siglo XVIII: tertulias, refrescos y cafés de Barcelona». Cuadernos de Historia Moderna, 2001, 26, pp. 11-55.

Pérez SAmper, M. á Á. "La historia de la historia de la alimentación». Chronica Nova, 2009, 35, pp. $105-162$. 
Pérez SAMPer, M. ${ }^{a}$ Á. «El chocolate en la España moderna: negocio y placer». En Franco RubIO, G. (coord.). Caleidoscopio de la vida cotidiana (siglos XVI-XVIII). Logroño: Editorial Siníndice, 2016, pp. 61-95.

PÉRez SAMPER, M. á Á. Comer y beber: una historia de la alimentación en España. Madrid: Cátedra, 2019.

Ponz Piquer, A. Viage de España, en que se da noticia de las cosas más apreciables y dignas de saberse, que hay en ella. Madrid: impresor Joaquín Ibarra, 1783.

Prado Antúnez, A. I. "Fiestas, romerías y bailes en el Bilbao del Antiguo Régimen: mecanismos de control y evolución de la fiesta y la comensalidad». Bidebarrieta, 2014, 25, pp. 57-71.

Qujada Álamo, D. «Lorenzo Sanz y Córdoba, un hombre de negocios con afición a los libros. La biblioteca de un mercader castellano (1764)». Tiempos Modernos, 2018, 37(2), pp. 52-78.

QuijaDA ÁlAmo, D. «La exaltación de las virtudes en la oración fúnebre de la reina María Josefa Amalia de Sajonia (1829)». En Torremocha Hernández, M. (ed.). Mujeres, sociedad y conflicto (siglos XVII-XIX). Valladolid: Castilla Ediciones, 2019, pp. 63-80.

Rial GarCía, S. «Casar doncellas pobres, paradigma de la caridad eclesiástica». Obradoiro de Historia Moderna, 1994, 3, pp. 71-85.

Sánchez GarCía, J. L. «La herencia de la Ilustración». En GarCía Colmenares, P. et al. (coords.). Historia de Palencia. Siglos XIX-XX. Palencia: El Norte de Castilla, 1996, pp. 7-12.

Terreros Pando, E. Diccionario castellano con las voces de ciencias y artes y sus correspondientes en las tres lenguas francesa, latina e italiana. Madrid: En la imprenta de la viuda de Ibarra, hijos y compañía, 1786.

TORREMOCHA HERNÁNDEZ, M. «Diversiones y fiestas en Valladolid durante el Antiguo Régimen». En Valladolid. Historia de una ciudad (época moderna). Valladolid: Ayuntamiento de Valladolid, 1999, pp. 491-510.

TORREMOCHA HERNÁNDEZ, M. "Presos pobres, pobres presos: asistencia en la cárcel de la ciudad de Valladolid (siglo XVII)». En Sobaler SeCO, M. a Á. et al. (coords.). Estudios en homenaje al profesor Teófanes Egido. Valladolid: Junta de Castilla y León, 2004, pp. 403-422.

TORREMOCHa HernánDEZ, M. «Espiritualidad y moralidad en el patrón de un juez perfecto en la Edad Moderna». En Pérez Álvarez, M. ${ }^{a}$ J. et al. (coords.). Religión, política y patrimonio en la Península Ibérica (siglos XIII-XXI). Madrid: Síntesis, 2018, pp. 167-188.

Torremocha Hernández, M. Cárcel de mujeres en el Antiguo Régimen. Teoría y realidad penitenciaria de las galeras. Madrid: Dykinson, 2019. 